\title{
Toplam Faktör Verimliliğinin Belirleyicileri: G-7 ve Seçilmiş Yükselen Piyasa Ekonomileri Üzerine Bir Uygulama (1992-2013)
}

\author{
Determinants of Total Factor Productivity: \\ An Application on The G-7 and Selected Emerging Market Economies (1992-2013)
}

\author{
Dr. Öğr. Üyesi Ömer Yalçınkaya
}

\begin{abstract}
Başvuru Tarihi: 15.01.2016
\end{abstract}
Kabul Tarihi: 04.08.2017

\section{Öz}

Ülke ekonomilerinin teknolojik gelişme düzeylerine bağl olan toplam faktör verimliliği artışları, uzun dönemde ekonomik büyümenin temel belirleyicisi olarak kabul edilmektedir. Bu kapsamda, toplam faktör verimliliği artışı üzerinde etkili olan unsurların belirlenmesi ve politikalar yoluyla bu faktörlerde iyileştirmelerin yapılması uzun dönemde potansiyel büyüme hızlarının artırılması ve sürdürülebilir kılınması açısindan büyük önem taşımaktadır. Bu çalışmada, G-7 ile Brezilya, Rusya, Hindistan, Çin, G. Afrika, Meksika, Endonezya, Türkiye ve S. Arabistan gibi hizh gelişmekte olan yükselen piyasa ekonomilerinde (YPE-9) toplam faktör verimliliğinin belirleyicileri 1992-2013 dönemi için ekonometrik olarak ayrı ayrı incelenmektedir. Çalışma sonucunda, G-7 grubunda fiziksel sermaye, bilgi, inovasyon ve teknolojik gelişmişlik düzeyini temsilen kullanılan hemen bütün değişkenlerin toplam faktör verimliliği artışı üzerinde önemli derecede etkili olduğu tespit edilmiştir. Buna karşıllk, YPE-9 grubunda sadece fiziksel sermaye yatırmlarinin toplam faktör verimliliği artışı üzerinde önemli derecede etkili olduğu belirlenmiştir. Bu sonuçlar inceleme döneminde, G-7 ve YPE-9 grubundaki ülkelerin uzun dönemde ekonomik büyüme performanslarının sürdürülebilirliği açısından farklilaşmalarının büyük ölçüde bilgi, inovasyon ve teknolojik gelişmişlik düzeyini temsilen kullamilan göstergelerden kaynaklandığın ortaya koymaktadır.

Anahtar Kelimeler: G-7, Seçilmiş Yükselen Piyasa Ekonomileri, Toplam Faktör Verimliliği, Panel Veri Analizi

\begin{abstract}
Total factor productivity increments depend on the technological advancement level of the country economies are accepted as the primary determinant of economic growth in the long term. In this context, determining the effective factors on the total factor productivity increment and being made improvements on these factors via policies have a place in increasing and make the potential growth rate sustainable in the long run. In this study, the determinants of total factor productivity for the fast-growing emerging market economies (EME-9) such as Brazil, Russia, India, China, South Africa, Mexico, Indonesia, Turkey and Saudi Arabia with G-7 countries are econometrically analyzed one by one for the period of 1992-2013. It is found at the end of the study that almost all variables used to represent the physical capital, knowledge, innovation and technological development level in the G-7 group are significantly active on the total factor productivity increment. On the other hand, it is pointed out through our research that just the physical capital investments in the EME-9 group are substantially influential on the total factor productivity increase. These results reveal for the investigation period that the differentiations of the counties in G-7 and EME-9 groups in terms of the sustainability of economic growth performance in the long-term mostly result from the indicators used on behalf of the knowledge, innovation, and technological advancement level.
\end{abstract}

Keywords: G-7, Selected Emerging Market Economies, Total Factor Productivity, Panel Data Analysis

Dr. Öğr. Üyesi Ömer Yalçınkaya, Ağrı İbrahim Çeçen Üniversitesi İktisadi ve İdari Bilimler Fakültesi, omeryalcinkaya84@hotmail.com 


\section{Giriş}

1980'lerin ikinci yarısından itibaren İçsel büyüme teorileri ile birlikte yeniden önem kazanmaya başlayan büyüme iktisadında, uzun dönemde ülkelerin ekonomik büyüme hızları arasında koşullu bir yakınsamanın olup olmadığı ve bunun nasıl gerçekleşebileceği temel sorular olarak araştırılmaktadır. Daha genel bir ifadeyle İçsel büyüme teorilerinin kapsadığı bu sorular, uzun dönemde gelişmekte olan ülkelerin gelişmiş ülkelerle aralarındaki gelir farkını kapatmak için makro iktisadi anlamda hangi politikaları izlemelerinin gerekli olduğu şeklinde ortak bir payda etrafinda toplanabilmektedir. Ülke ekonomilerinde yeni büyüme iktisadının gündeme getirdiği bu soruların yanıtları aranırken, süreç içerisinde dünya genelinde çeşitli ülkelerin uyguladıkları makroekonomik politikaların da giderek birbirine benzediği görülmektedir.

Özellikle 1990 'lı yıllarda sosyalist blokun yıkılmasının ardından daha da hızlanan bu sürecin, Washinghton Konsensusu olarak bilinen ekonomik politika yaklaşımlarıyla neredeyse bütün ülkelerin uyguladıkları makroekonomik politikaların genel çerçevesinin birlikte belirlendiği bir ortamla evrildiği izlenmektedir. Bu kapsamda, gelişmiş ve gelişmekte olan ülkelerin uyguladıkları makroekonomik politikalarda istikrarlılık ve neredeyse yeknesaklık sağlanmasına karşın, söz konusu ülke gruplarının ekonomik büyüme performanslarında farklılıkların oluşmasının önüne geçilemediği de anlaşılmaktadır. Bu tarihten itibaren süregelen gelişmiş ve gelişmekte olan ülkelerin uzun dönemli ekonomik büyüme performansları arasındaki farklılıklar başta kurumsal yapı olmak üzere bir dizi alanda gerekli dönüşümün sağlanamamasından kaynaklanmakta ve günümüzde farklı ölçülerde olsa bile devam etmektedir. Bu durum, bir yandan günümüz gelişmekte olan ülkelerinin gelişmiş ülkelerin geçmiş dönemlerindeki ekonomik ortamdan çok daha farklı bir ortamda ekonomik büyümeyi sağlamalarını ve sürdürmelerini gerekli kılmakta, diğer yandan da büyüme iktisadının geçmiş dönemdeki temel sorularını farklı biçimlerde yeniden gündeme getirmektedir.

Gelişmiş ve gelişmekte olan ülkelerin ekonomik büyüme hızları arasındaki farklılıklar nereden kaynaklanmaktadır? Ülkelerin ekonomik büyüme hıları coğrafik-jeopolitik konum, doğal kaynaklar, nüfus gibi bazı temel faktörler tarafından $\mathrm{m}$ belirlenmektedir? Bu durumda, ülkelerde izlenecek makroekonomik politikalar uzun dönemli ekonomik büyüme performansı üzerinde çok fazla etkili olmayacaktır. Aksine, ülkelerdeki iktisadi karar birimleri uygulayacakları makroekonomik politikalarla ekonomik büyüme hızını etkileme imkânına sahipler midir? Eğer böyleyse, hangi politika uygulamaları ülkelerin uzun dönemli ve sürdürülebilir ekonomik büyüme performansları üzerinde daha fazla etkili olacaktır? (İzmen vd., 2005, s.19-25). Bu türden soruların yanıtlarını arayan büyüme iktisadının günümüzde ulaştığ 1 noktada, gelişmiş ve gelişmekte olan ülkeler arasındaki gelir farklılıklarının azalmasının kendiliğinden bir süreç olmadığına, doğru makroekonomik politikaların da bir ön şart olmakla birlikte yeter şart olmadığına işaret edilmektedir. Bu bağlamda, ekonomik büyümenin kaynağında verimlilik artışının olması şeklinde tanımlanabilen sürdürülebilir büyüme kavramının, bir yandan gelişmiş ülke deneyimleri diğer yandan da İçsel büyüme yaklaşımlarıly birlikte gelişmekte olan ülkelerin ekonomik politika oluşturma gündemlerinin ilk sıralarında yer almaya başladığı görülmektedir.

Nitekim ekonomik büyüme, ekonominin kurumsal yapısındaki gelişmeler dışında üretim sürecinde kullanılan faktörlerdeki birikimden ve/veya bu faktörlerdeki verimlilik artışından kaynaklanmakta, faktör birikimi üretim süreci için gerekli olan girdileri, verimlilik artışı ise ekonomik birimlerin bu girdilerle üretim yapma yeteneğini ifade etmektedir. Verimlilik artışı olmaksızın ekonomik büyüme; emek, sermaye ve doğal kaynak arzı gibi faktörlerin birikim sınırlarını belirleyen etkilere maruz kalmakta ve üretim faktörleri sürekli artırılabilse bile bu faktörlerdeki ölçeğe göre azalan getiri olgusu ekonomik büyümeyi kısıtlamaktadır. Ekonomik büyümeye verimlilik artışının eşlik etmesi durumunda ise bu kısıtlar etkin olmaktan çıkmakta ve birim çıtının daha az girdi ile üretilmesi sağlanarak uzun dönemde ekonomik büyümenin sürdürülebilmesi için gerekli olan ekonomik temeller atılmaktadır (Serdaroğlu, 2013, s.1-2).

Dolayısıyla sadece faktör birikimine dayalı ekonomik büyüme süreçlerinin doğal sınırları dikkate alınarak bu faktörlerde verimlilik artışlarının sağlanması ve sürekli kılınması konusuna önem verilmesi gerekmektedir. Bu kapsamda, üretimde kullanılan bütün faktörlerin verimliliğini içeren toplam faktör verimliliği artışı üzerinde etkili olan unsurların belirlenmesi ve politikalar yoluyla bu faktörlerde iyileştirmelerin yapılması uzun dönemli potansiyel büyüme hızları- 
nın artırılması ve sürdürülebilir kılınması açısından büyük önem taşımaktadır. Toplam faktör verimliliğinin belirleyicilerinin ise orta ve uzun vadeli bir yaklaşımla genellikle dört ana başlık altında toplandığ görülmektedir. Buna göre, ülkelerin dış dünyayla bütünleşme dereceleri (genelde ticaret yoluyla), kurumsal yapıları ve coğrafi özellikleri bu konudaki uzun vadeli belirleyiciler olarak kabul edilmektedir. Buna karşılık, toplam faktör verimliliğinin uzun vadeli unsurlarından tamamen bağımsız olmayan orta vadeli belirleyicilerinin; yenilikçilik ve bilginin edinimiaktarımı, faktör arzı ve etkin dağılımı ve son olarak rekabetçi yapı, sosyal boyut ile çevresel faktörler şeklinde olduğu belirtilmektedir (Isaksson, 2007, s.1-4).

Bu noktadan hareketle çalışmada, sürdürülebilir ekonomik büyümenin temelini oluşturan toplam faktör verimliliğinin uzun vadeli belirleyicilerinin neler olduğu gelişmiş ülkeler (G-7) ile Brezilya, Rusya, Hindistan, Çin, G. Afrika, Meksika, Endonezya, Türkiye ve S. Arabistan gibi hızlı gelişmekte olan yükselen piyasa ekonomileri (YPE-9) üzerinde ayrı ayrı incelenecektir. Bu genel amaçla birlikte, çalışmada toplam faktör verimliliği artışı üzerinde etkili olan unsurların söz konusu ülke gruplarının uzun dönemli ekonomik performans açısından farklılaşmaları üzerinde ne derece etkili olduğunun değerlendirilmesi ve farklılaşmanın daha çok hangi makroekonomik değişkenlerden kaynaklandığının ortaya konulması amaçlanmaktadır.

Bu kapsamda, girişi takiben ikinci bölümde toplam faktör verimliliğinin belirleyicilerini araştıran ilgili literatür ana hatlarıla özetlenmektedir. Üçüncü bölümde çalışmada kullanılan ekonometrik modelin metodolojisi kısaca açılanmakta ve modellerde içerilen veri seti tanıtılmaktadır. Çalışmanın dördüncü bölümünde, gelişmiş (G-7) ve gelişmekte olan (YPE-9) ülke grupları üzerinde toplam faktör verimliliğinin belirleyicileri 1992-2013 dönemi için ampirik olarak ayrı ayrı incelenmekte ve çalışma genel değerlendirmelerin yer aldığı sonuç bölümüyle tamamlanmaktadır.

\section{Literatür Özeti: Toplam Faktör Verimlili- ğinin Belirleyicileri}

Bir ekonomideki teknolojik gelişme düzeyine bağlı olan toplam faktör verimliliği artışları uzun dönemde ekonomik büyümenin temel belirleyicisi olarak kabul edilmektedir. Bu yönüyle toplam faktör ve- rimliliği artışının belirleyicilerinin araştırılması bir bakıma uzun dönemli ekonomik büyümeyi etkileyen unsurların araştırılması anlamına gelmektedir. İlgili literatür incelendiğinde, toplam faktör verimliliğinin ülkeler arasındaki refah düzeyi (gelir) farklılıklarını açılamadaki rolü üzerinde durulmakta, toplam faktör verimliliği artışları ile onu etkileyen unsurların gelişmiş ve gelişmekte olan ülkeler arasındaki gelir farklılıklarının önemli bir bölümünü açıklayabileceği kabul edilmektedir (Ascari ve Cosmo, 2005, s.1-2).

Literatür incelendiğinde farklı ülke grupları üzerinde toplam faktör verimliliğini etkileyen unsurları belirlemeye yönelik olarak mikro ve makroekonomik temelli ve sektörel düzeyde birçok çalışmanın yapıldığı görülmektedir. Yapılan çalışmalar sonucunda özelikle gelişmiş ülke ekonomilerinde araştırma geliştirme yatırımları ve patent sayıları gibi bilgi ve inovasyon seviyesini temsil eden değişkenlerin toplam faktör verimliliği üzerinde genellikle pozitif yönlü bir etkiye sahip olduğu belirlenmiştir. (Lichtenberg ve Siegel (1991), Hall ve Mairesse (1995), Abdih ve Joutz (2005), Griffith vd., (2000), Guellec ve Van Pottelsberghe De La Potterie (2001), Ulku (2004), Furman ve Hayes (2004)). Ancak sınırlı sayıdaki bazı çalışmalarda ise bilgi ve inovasyon seviyesini temsilen kullanılan söz konusu değişkenlerin toplam faktör verimliliği üzerinde herhangi etkisinin olmadığı sonucuna ulaşılmıştır.(Bartelsmann vd., (1996), Comin (2002)).

Diğer taraftan, yapılan çalışmaların sonucunda beklenildiği gibi doğrudan yabancı yatırımların bilgi yayılımı, teknoloji transferi, finansal gelişmişlik seviyesi ile beşeri ve fiziksel sermayenin niteliğini arttırma yoluyla toplam faktör verimliliği üzerinde genellikle pozitif bir etkiye sahip olduğu belirlenmiştir. (Haskel vd., (2002), Keller ve Yeaple (2003), Griffith vd., (2003), Hermes ve Lensink (2003), Loko ve Diouf (2009), Alfaro vd., (2009)). Bilgi ve inovasyon değişkenlerinde olduğu gibi doğrudan yabancı yatırımların da toplam faktör verimliliği üzerinde herhangi bir etkisinin olmadığı sonucuna ulaşan çalışmalar da bulunmaktadır. (Aitken ve Harrison (1999) ve Hanson (2001)). Dış ticaret yoluyla sınırlı sayıdaki yenilikçi ülkelerdeki ileri teknoloji ürünleri ülke içerisindeki üretim sürecine dâhil olduğundan, ülkelerin dişa açıklık derecesi attıkça teknoloji transferinden yararlanma derecelerinin de artacağı beklenmektedir. Gelişmiş ve gelişmekte olan ülke ekonomileri üzerinde yapılan ampirik çalışmaların sonucunda dış ticaretin 
teknoloji transferi yoluyla toplam faktör verimliliği üzerinde genellikle pozitif bir etkiye sahip olduğu belirlenmiştir. (Coe ve Helpman, (1995), Coe vd., (1997), Isaksson (2001), Miller ve Upadhyay (2002), Loko ve Diouf (2009)). Toplam faktör verimliliği üzerinde pozitif bir etkiye sahip olması beklenen diğer bir faktörün ise beşeri sermayenin özellikle eğitim boyutuyla olduğu görülmektedir. Eğitim, üretim faktörlerinden biri olan işgücünü daha donanımlı bir hale getirerek, toplam faktör verimliliği üzerinde pozitif bir etkiye sahip olmasını sağlamaktadır. Yapılan çalışmalar orta ve yüksek gelirli ülkelerde eğitim değişkeninin toplam faktör verimliliği üzerinde genellikle pozitif bir etkisinin olduğunu ortaya koymaktadır. (Bartel (1992), Black ve Lynch (1995), Miler ve Upadhyay (2000), Loko ve Diouf (2009)). Bununla birlikte, ilgili literatür incelendiğinde düşük gelirli ülkelerde eğitim değişkenlerinin toplam faktör verimliliği üzerindeki etkisinin negatif yönlü olduğu belirlenmiştir. (Miler ve Upadhyay (2000)).

Literatürde toplam faktör verimliliği üzerinde genellikle pozitif bir şekilde etkili olduğu düşünülerek farklı ülke grupları için araştırılan diğer değişkenlerin ise fiziksel altyapı, finansal sistem, yapısal dönüşüm, kurumsal ve coğrafik yapı, rekabetçilik, sosyal boyut ve çevresel faktörler şeklinde olduğu görülmektedir. (Easterly ve Levine (2002), Aghion vd., (2005), Jaumotte ve Spatafora (2007), Loko ve Diouf (2009), Alfaro vd., (2009), Mastromarco ve Zago (2012)). ${ }^{1}$ Literatürde toplam faktör verimliliğinin belirleyicilerini tespit etmek üzere yürütülen çalışmalar bir bütün olarak incelendiğinde, genellikle gelişmiş ülkeler olmakla birlikte farklı ülke grupları üzerinde makro ekonomik temelli veya sektörel düzeyde ampirik çalışmaların yapıldığı görülmektedir. Çalışmalarda genellikle birçok değişkenin toplam faktör verimliliği üzerindeki etkisinin bir bütün olarak araştırıldığı, ancak bazı çalışmalarda (özellikle sektörel düzeyde yapılan) başta bilgi ve inovasyon değişkenleri olmak üzere sadece bir değişkenin toplam faktör verimliliği üzerinde etkisinin araştırıldığı izlenmektedir. Bu çalışmada, literatür incelemesinin ardından toplam faktör verimliliği üzerinde en fazla etkili olduğu belirlenen değişkenlerin gelişmiş (G-7) ve gelişmekte olan

1 TFP’nin belirleyicileri hakkında kapsamlı bir literatür taraması için bakınız, Anders, Isaksson. (2007). Determinants of Total Factor Productivity: A Literature Review (United Nations Industrial Development Organization, Research and Statistics Branch Staff Working Paper No. 02). Vienna: UNIDO. ülkeler yükselen piyasa ekonomileri (YPE-9) üzerinde makro ekonomik temelde incelenmesi amaçlanmaktadır. Böylelikle her iki ülke grubunda toplam faktör verimliliğinin belirleyicilerinin ayrı ayrı incelenmesi ve ortaya çıkan sonuçların ifade ettiklerinin ülke gruplarının ekonomik gelişmişlik seviyesi açısından değerlendirilmesi amaçlanmaktadır.

\section{Araştırma Yöntemi ve Veriler}

Çalışmanın bu bölümünde, G-7 (ABD, Almanya, Fransa, İngiltere, İtalya, Japonya, Kanada) ile Brezilya, Rusya, Hindistan, Çin, G. Afrika, Meksika, Endonezya, Türkiye ve S. Arabistan gibi hızlı gelişmekte olan yükselen piyasa ekonomilerinde (YPE-9) toplam faktör verimliliğinin belirleyicileri 1992-2013 dönemi için yıllık bazda ve ekonometrik olarak incelenmektedir. ${ }^{2}$ Diğer bir deyişle çalışmada, G-7 ve YPE-9 ülke gruplarında sürdürülebilir ekonomik büyümenin temelini oluşturan toplam faktör verimliliği artışı üzerinde uzun vadede etkili olan unsurların ayrı ayrı tespit edilmesi ve ortaya çıkan sonuçların ifade ettiklerinin ülke gruplarının ekonomik gelişmişlik seviyesi açısından değerlendirilmesi amaçlanmaktadır. Böylelikle çalışmada söz konusu ülke gruplarının uzun dönemli ekonomik performans açısından farklılaşmalarının daha çok hangi makroekonomik değişkenlerden kaynaklandığının ortaya konulması tasarlanmaktadır.

Bu kapsamda, G-7 ve YPE-9 ülke gruplarında fiziksel ve beşeri sermaye ile bilgi, inovasyon ve teknolojik gelişmişlik seviyesini temsilen kullanılan değişkenlerin toplam faktör verimliliği üzerindeki uzun dönemli etkileri panel veri analiziyle incelenmekte, toplam faktör verimliliği artışı üzerinde etkili olan unsurların yönü ve büyüklüğü tespit edilmektedir ${ }^{3}$. Zaman boyutuna sahip yatay kesit veriler diğer bir deyişle panel veriler kullanılarak oluşturulan modellerle ekonomik ilişkilerin tahmin edilmesine "Panel Veri Analizi” denilmektedir. Genel olarak panel veri modeli;

2 Toplam faktör verimliliğinin hesaplanma yöntemi hakkında kapsamlı bilgi için bakınız: (Saygılı vd., 2005, s.92-93). Sovyet Sosyalist Cumhuriyetler Birliğiınin (SSCB) 1991 yllında dağılması ile birlikte bağımsızlı̆̆ını ilan eden Rusya Federasyonu'nun önceki dönemlerine ait verilerin elde edilmesinde karşılaşılan kısıtlar, çalışmanın inceleme döneminin 1992 yılı ile başlatılmasını gerektirmiştir.

3 Çalışmada tanımlanan modellerin tahmin edilmesinde EViews 9.0, Stata 14.00 paket programı ve Gauss 10.0 paket programı ile bu program için yazılan kodlar kullanılmıştır. 


$$
Y_{i t}=\alpha_{i t}+\beta_{k i t} X_{k i t}+u_{i t} \quad i=1, \ldots \ldots, N ; \quad t=1, \ldots \ldots, T
$$

şeklinde yazılabilmektedir. Burada; Y: Bağımlı değişkeni, $X_{i k}$ : Bağımsız değişkenleri, : Sabit parametreyi, $\beta$ : Eğim parametrelerini, $u$ : Hata terimini i: Alt indisi birimleri (birey, firma, şehir, bölge, ülke gibi) t: Alt indisi ise zamanı (gün, hafta, ay, yıl gibi) temsil etmektedir (Tatoğlu, 2012, s.4). Bu çalışmada, gelişmiş ve gelişmekte olan yükselen piyasa ekonomilerinde toplam faktör verimliliğinin belirleyicileri incelenirken, ilgili ülkelerde toplam faktör verimliliği artışı üzerinde etkili olan dinamiklerin ve dolayısıyla değişkenler arasındaki ilişkilerinin farklılıklar gösterebileceğinin dikkate alınması gerekmektedir. Bununla birlikte, modellerde kullanılan seriler arasında çoklu doğrusal bağlantı sorunuyla da karşılaşmamak için çalışmada uzun dönemde toplam faktör verimliliğinin belirleyicilerinin farklı modeller yardımıla incelenmesi yoluna gidilecektir. Çalışmada G-7 ve YPE-9 gruplarında toplam faktör verimliliğinin uzun dönemli belirleyicilerini tespit etmek üzere kurulan modellerde kullanılan değişkenler ve kaynakları Tablo 1'de sunulmaktadır. Çalışmada G-7 ve YPE-9 gruplarının her biri için ayrı ayrı tahmin edilecek ekonometrik modeller aşağıdaki eşitliklerde gösterilmektedir:

$$
\begin{aligned}
& \text { Model-1: } T F P_{i t}=\alpha_{i t}+\beta_{1} G F C F_{i t}+\beta_{2} E L_{i t}+\beta_{3} E I_{i t}+u_{i t} \\
& \text { Model-2: } T F P_{i t}=\alpha_{i t}+\beta_{1} G F C F_{i t}+\beta_{2} E L_{i t}+\beta_{3} F D I_{i t}+u_{i t} \\
& \text { Model-3: } T F P_{i t}=\alpha_{i t}+\beta_{1} G F C F_{i t}+\beta_{2} E L_{i t}+\beta_{3} X M_{i t}+u_{i t} \\
& \text { Model-4: } T F P_{i t}=\alpha_{i t}+\beta_{1} G F C F_{i t}+\beta_{2} E L_{i t}+\beta_{3} H T E_{i t}+u_{i t} \\
& \text { Model-5: } T F P_{i t}=\alpha_{i t}+\beta_{1} G F C F_{i t}+\beta_{2} E L_{i t}+\beta_{3} A R-G E_{i t}+u_{i t} \\
& \text { Model-6: } T F P_{i t}=\alpha_{i t}+\beta_{1} G F C F_{i t}+\beta_{2} E L_{i t}+\beta_{3} P A T_{i t}+u_{i t}
\end{aligned}
$$

Çalışmada G-7 ve YPE-9 ülke gruplarında uzun dönemde toplam faktör verimliliğinin belirleyicilerini tespit etmek üzere yukarıda tanımlanan modellerin panel veri analizi metodolojisi ile başlıca dört aşamada incelenmesi amaçlanmıştır. İlk aşamada, modellerde kullanılan değişkenlerde ve eş-bütünleşme denklemlerinde paneli oluşturan (YKB) yatay kesitler arasındaki bağımlılık LM (Lagrange Multiplier) testleriyle incelenmiştir. G-7 ve YPE-9 grubunda tanımlanan modellerin büyük bir bölümümde YKB'nin olduğu bazılarında ise YKB'nin olmadığg belirlendiğinden, kurulan modellerin birinci ve ikinci nesil (YKB'yi dikkate alan) testleri kullanarak tahmin edilmesi gerektiği anlaşılmıştır. Bu bağlamda, ikinci aşamada serilerin durağanlığı birinci ve ikinci nesil panel birim kök testleri ile araştırılmıştır. Tanımlanan modellerde kullanılan bütün değişkenlerin aynı mertebeden $[\mathrm{I}(1)]$ durağan olduklarının belirlenmesinin ardından üçüncü aşamada değişkenler arasında olması muhtemel uzun dönemli ilişkiler yine birinci ve ikinci nesil panel eş-bütünleşme testleriyle incelenmiştir. Dördüncü ve son aşamada, panel eşbütünleşme testleriyle saptanan uzun dönemli eşbütünleşme ilişkisinin katsayılarının DSUR ve DOLS tahmincileriyle incelenmesi yoluna gidilmiştir. 
Tablo 1. Modelde Kullanılan Değişkenler ve Kaynakları

\begin{tabular}{|c|c|c|}
\hline \multicolumn{3}{|c|}{ İnceleme Dönemi: 1992-2013 } \\
\hline Değişkenler & Tanımı & Veri Kaynağı \\
\hline TFP & Toplam Faktör Verimliliği (Tornqvist Index). & \multirow{2}{*}{$\begin{array}{l}\text { The Conference Board } \\
\text { (Total Economy Database May 2015). }\end{array}$} \\
\hline $\mathbf{E L}$ & İstihdam Edilen İşgücü & \\
\hline GFCF & Sabit Sermaye Yatırımları & \multirow{4}{*}{ WB (World Development Indicators). } \\
\hline FDI & Doğrudan Yabancı Yatırımlar & \\
\hline $\mathbf{X M}$ & Dışa Açıklık Göstergesi & \\
\hline HTE & Yüksel Teknoloji İhracatı & \\
\hline EI & Eğitim Endeksi & Penn World Table (Version 8.1). \\
\hline AR-GE & Araştırma-Geliştirme Yatırımları & \multirow{2}{*}{ OECD. Stat. } \\
\hline PAT & Patent Başvuruları (Toplam Sayı) & \\
\hline \multirow{5}{*}{ Açıklama } & \multicolumn{2}{|c|}{$\begin{array}{l}\text { GFCF değişkeni; ilgili veri tabanından reel (2005-USD) olarak alınmıștır. Bununla birlikte, Suudi } \\
\text { Arabistan için ilgili veri nominal (USD) olarak alınmış ve ülkenin GSYİH deflatörüne oranlanarak reel } \\
\text { hale getirilmiştir. }\end{array}$} \\
\hline & \multirow{2}{*}{\multicolumn{2}{|c|}{$\begin{array}{l}\text { FDI ve HTE değişkenleri; ilgili veri tabanından nominal (USD) olarak alınmış ve ülkelerin GSYİH } \\
\text { deflatörlerine oranlanarak reel hale getirilmiştir. } \\
\text { EI değişkeni; aktif nüfusun İlköğretim, Ortaöğretim ve Yükseköğretim olmak üzere farklı eğitim } \\
\text { kademelerindeki ortalama okullaşma yılı (Barro-Lee; 2012) ve aynı eğitim kademelerindeki getiri } \\
\text { oranlarına (Psacharopoulos; 1994) dayalı olarak kişi başına değerler cinsinden hesaplanan eğitim endeksi } \\
\text { değerini temsil etmektedir. Ayrıca, EI değişkeni ilgili veri tabanında } 2012 \text { ve } 2013 \text { yılları için eksik } \\
\text { olduğundan, bu veriler tüm ülkeler için EViews } 9.0 \text { paket programında Cubic Spline metodu ile tahmin } \\
\text { edilerek analize dâhil edilmiştir. }\end{array}$}} \\
\hline & & \\
\hline & \multicolumn{2}{|c|}{$\begin{array}{l}\text { XM değişkeni; ülkelerin reel (2005-USD) mal ve hizmet ihracat ve ithalat değerleri toplamının reel GSYİH } \\
\text { (2005-USD) oranlanmasıyla elde edilmiştir. Bununla birlikte, Suudi Arabistan için ilgili veriler nominal } \\
\text { (USD) olarak alınmış ve ülkenin GSYİH deflatörüne oranlanarak reel hale getirilmiştir. }\end{array}$} \\
\hline & \multicolumn{2}{|c|}{$\begin{array}{l}\text { AR-GE değişkeni, OECD veri tabanından nominal (USD) olarak alınan Araştırma ve Geliştirme } \\
\text { Yatırımlarını, WB veri tabanındaki ilgili ülkelerin GSYIH deflatörlerine oranlanmasıyla reel hale } \\
\text { getirilmiştir. Ayrıca, AR-GE değişkeni ilgili veri tabanında yükselen piyasa ekonomilerinden Rusya, Çin, } \\
\text { Meksika ve Türkiye için mevcut olduğundan YPE-9 için AR-GE değişkeni sadece bu dört ülkenin verisi } \\
\text { kullanılarak oluşturulmuştur. }\end{array}$} \\
\hline Not: & \multicolumn{2}{|c|}{$\begin{array}{l}\text { Modellerde kullanılan TFP, GFCF, EL, EI, FDI, XM ve HTE değişkenleri ilgili dönem aralığındaki yıllık büyüme } \\
\text { hızı rakamlarıyla ve AR-GE ile PAT değişkenleri ise logaritmik değerleriyle analizde kullanılmışlardır. }\end{array}$} \\
\hline
\end{tabular}

\section{Bulgular}

\section{Yatay Kesit Bağımsızlığı Test Sonuçları ve Değerlendirilmesi}

Panel verilerde zaman serisi verilerinde olduğu gibi serilerin durağan olması önem taşımakta, durağan olmayan seriler ile analiz yapıldı̆̆ında sahte regresyon olgusu ile karşılaşılabilmekte, diğer bir deyişle sapmalı $\mathrm{t}$, $\mathrm{F}$ testleri ve $\mathrm{R}^{2}$ değerleri elde edilebilmektedir. Bu nedenle, panel veri çalışmalarında güvenilir sonuçlar elde edebilmek için öncelikle serilerin durağan olup olmadıklarının test edilmesi gerekmektedir (Tatoğlu, 2013, s.199). Bununla beraber, panel verilerin durağanlığını tespit etmek için kullanılacak birim kök testleri de paneli oluşturan birimlerde yatay kesit bağımlılı̆̆ının olup olmamasına göre birinci nesil ve ikinci nesil panel birim kök testleri olarak ikiye ayrılmaktadır. Birinci nesil panel birim kök testlerinde seriyi oluşturan yatay kesitlerin birbirinden bağımsız olduğu yani seriyi oluşturan birimlerden birine gelen şoktan bütün birimlerin aynı oranda etkilendikleri varsayılmaktadır. İkinci nesil panel birim kök testleri ise paneli oluşturan birimlerden birine gelen şoklardan her birimin aynı şekilde etkilenmeyebileceği varsayımına dayanmaktadır.

$\mathrm{Bu}$ yönüyle paneli oluşturan birimler arasında yatay kesit bağımlılığının olması durumunda birinci nesil panel birim kök testlerinin güvenilir sonuçlar vermeyeceği genellikle kabul edilmektedir. Böyle bir durumda paneli oluşturan birimler arasında yatay kesit bağımlılığına izin veren (Taylor ve Sarno, 1998; Breuer, McNown ve Wallace, 2002; Pesaran, 2007; Hadri ve Kurozumi, 2012) vb. ikinci nesil Panel Birim Kök Testleri kullanılabilmektedir. Bu çerçevede, panel veri çalışmalarında analize başlamadan önce serilerde ve eş-bütünleşme denkleminde yatay kesit bağımlılığının araştırılması ve kullanılması gereken birim kök, eş-bütünleşme ve diğer testlerin belirlenmesi gerekmektedir. Aksi halde yapılan analizlerin sapmalı olabileceği ve hatalı sonuçlar verebileceği ifade edilmektedir (Göçer, vd., 2012, s.455-456). 
Yatay kesit bağımsızlığı, paneli oluşturan birimlerin herhangi birinde meydana gelen bir şoktan her birimin aynı şekilde etkileneceği anlamına gelmektedir. Birinci nesil panel birim kök testleri bu varsayıma göre oluşturulduğundan yatay kesitlerin bağımsız olduğunu varsaymaktadırlar. Ancak, ülke verileri ile çalışıldığ 1 zaman meydana gelen bir şoktan paneli oluşturan birimlerin farklı düzeylerde etkileneceğini söylemek daha gerçekçi bir yaklaşım olarak benimsenmektedir. Diğer yandan, panel verilerde yatay kesit bağımsızlığını tespit edebilmek için serinin zaman ve yatay kesit boyutunun göz önüne alınması gerekmektedir. Zira panelin zaman boyutu yatay kesit boyutundan büyük olduğunda $(\mathrm{T}>\mathrm{N})$ Breusch ve Pagan (1980) CD-LM1 testi; zaman boyutunun yatay kesit boyutundan küçük olduğu $(\mathrm{T}<\mathrm{N})$ veya zaman boyutunun yatay kesit boyutuna eşit olduğu $\quad(\mathrm{T}=\mathrm{N})$ durumlarda ise Pesaran (2004) CD-LM2 testi kullanılabilmektedir. Ancak, Breusch ve Pagan (1980) CDLM1 testi grup ortalamasının sifir fakat birim ortalamasının sıfırdan farklı olduğu durumlarda sapmalı sonuçlar vermektedir. Pesaran vd., (2008) yapmış oldukları çalışmalarında test istatistiğine varyansı ve ortalamayı ekleyerek bu sapmayı düzeltmişlerdir. $\mathrm{Bu}$ nedenle, test istatistiği düzeltilmiş LM testi olarak (CD-LM ${ }_{\text {adj }}$ ) ifade edilmektedir (Göçer, vd., 2013, s.66). Breusch ve Pagan (1980) makalesinde LM testi ilk hali ile aşağıdaki gibi tanımlanmaktadır;

$$
\mathrm{LM}=\mathrm{T} \sum_{\mathrm{i}=\mathrm{j}}^{\mathrm{n}-1} \sum_{\mathrm{j}=\mathrm{i}+1}^{\mathrm{n}} \breve{\rho}_{i j}^{2}
$$

Burada $\breve{\rho}_{i j}^{2}$ aşağıda gösterildiği gibi hata serileri arasındaki çift yönlü korelasyonu temsil etmektedir.

$$
\breve{\rho}_{i j}=\breve{\rho}_{j i}=\frac{\sum_{t=1}^{\mathrm{T}} e_{i t} e_{j t}}{\left(\sum_{t=1}^{\mathrm{T}} e_{i t}^{2}\right)^{1 / 2}\left(\sum_{t=1}^{\mathrm{T}} e_{j t}^{2}\right)^{1 / 2}}
$$

Bu denklemde en küçük kareler yöntemi ile T gözlem için $\mathrm{i}=1, \ldots . . . \mathrm{N}^{\prime}$ giderken her birimden elde edilen hata serilerini temsil etmektedir. Ancak, MonteCarlo simülasyonları Breusch ve Pagan (1980) standart LM testinin $\mathrm{N}>\mathrm{T}$ olduğunda iyi sonuçlar vermediğine işaret etmektedir. Pesaran (2004) yürüttüğü çalışmasında, aşağıda gösterildiği gibi bireysel olarak oluşturduğu regresyonların hata serileri arasındaki korelasyon katsayısının ortalamasını alarak elde ettiğ $\mathrm{i}$ CD-LM2 testi ile bu eksikliği gidermiştir.
$\mathrm{CD}=\sqrt{\frac{2 T}{N(N-1)}}\left(\sum_{\mathrm{i}=\mathrm{j}}^{\mathrm{n}-1} \sum_{\mathrm{j}=\mathrm{i}+1}^{\mathrm{n}} \breve{\rho}_{i j}^{2}-1\right)$

Pesaran tarafindan geliştirilen bu testin, Breusch ve Pagan (1980) testinin aksine N'nin büyük T’nin küçük olduğu durumlarda da iyi sonuçlar verdiği gözlemlenmiştir. Bununla beraber, gurup ortalamasının sıfır ancak birim ortalamasının sıfırdan farklı olduğu durumlarda iyi sonuçlar vermeyen LM testi Pesaran ve diğerleri tarafından 2008 yılında yapılan çalışmada aşağıdaki gibi geliştirilmiştir.

$\mathrm{LM}_{\text {adj }}=\mathrm{NLM}^{* *}=\sqrt{\frac{2 T}{N(N-1)}}\left(\sum_{\mathrm{i}=\mathrm{j}}^{\mathrm{n}-1} \sum_{\mathrm{j}=\mathrm{i}+1}^{\mathrm{n}} \frac{(\mathrm{T}-\mathrm{K}) \breve{\rho}_{i j}^{2}-\mu_{\mathrm{Tij}}}{\mathrm{v}_{\mathrm{Tij}}}\right)(11)$

Yazarlar bu çalışmalarında test istatistiğine birimlerin ortalamasını $\left(\mu_{\mathrm{Tij}}\right)$ ve varyansını $\left(v_{\mathrm{Tij}}\right)$ dâhil ederek elde ettikleri yeni istatistiğinin; bireysel ortalamanın sıfırdan farklı olduğu durumlarda Pesaran (2004) CD-LM2 testinden daha tutarlı sonuçlar verdiğini belirtmişlerdir (Pesaran vd., 2008, s.105-127). Buradan elde edilecek olan test istatistikleri asimtotik olarak standart normal dağılım göstermekte ve testin hipotezlerini aşağıdaki ifade etmek mümkün olmaktadır;

$\mathrm{H}_{0}=$ Birimler arasında yatay kesit bağımlılığı yoktur.

$\mathrm{H}_{1}=$ Birimler arasında yatay kesit bağımlılığı vardır.

Test sonucunda elde edilecek olasılık değeri \% 5 önem düzeyinde 0.05 'ten küçük olduğunda (test istatistik değeri tablo değerinden büyük olduğunda) $\mathrm{H}_{0}$ temel hipotezi \%5 anlamlılık düzeyinde reddedilmekte ve alternatifi $\mathrm{H}_{1}$ kabul edilmektedir. Bu durumda, paneli oluşturan birimler arasında yatay kesit bağımlılı̆̆ının olduğuna karar verilmektedir. Yatay kesit bağımsızlığını araştıran testler ve bunların hipotezleri belirtildikten sonra ilk olarak yukarıda tanımlanan modellerde kullanılan değişkenlerde ve eş-bütünleşme denklemlerinde yatay kesit bağımlılı̆̆ının varlı̆̆ 1 CD-LM adj testi ile incelenmiş ve elde edilen sonuçlar Tablo 2'de sunulmuştur. ${ }^{4}$ Tablo 2'deki CD-LMadj test sonuçları G-7 ve YPE-9 grubunda modellerde

4 Çalışmada, tanımlanan G-7 ve YPE-9 gruplarında ülke sayıları sirasiyla $7(\mathrm{~N}=7)$ ve $9(\mathrm{~N}=9)$ ve her iki grupta inceleme dönemi 22 yıl olduğundan $(\mathrm{T}=22)$ tanımlanan modellerde kullanılan serilerde ve eş-bütünleşme denklemlerindeki yatay kesit bağımlılığı yukarıda açılanan ( $>\mathrm{N}$ ) spesifikasyona uygun ola-

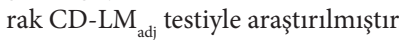


yer alan değişkenler açısından incelendiğinde tüm değişkenlere ait (YPE-9 grubu için AR-GE değişkeni hariç) $\mathrm{CD}-\mathrm{LM}_{\text {adj }}$ test istatistiği olasıllk değerlerinin 0.01 'den küçük olduğu görülmektedir. Bu nedenle, G-7 grubunda modellerde yer alan bütün değişkenler ve YPE-9 grubunda ise AR-GE değişkeni dışındaki tüm değişkenler için CD-LMadj testine göre tanım- lanan $\mathrm{H}_{0}$ hipotezlerinin (birimler arasında yatay kesit bağımlılı̆̆1 yoktur) güçlü bir biçimde reddedilmesi ve alternatif hipotezlerin kabul edilmesi gerekmektedir. Bu durum, G-7 ve YPE-9 grubu panelini oluşturan ülkeler arasında YPE-9 grubu için AR-GE değişkeni dışındaki diğer tüm değişkenler açısından yatay kesit bağımlılığının bulunduğu anlamına gelmektedir.

Tablo 2. Yatay Kesit Bağımsızlığı Test Sonuçları (CD-LM $\left.{ }_{a d j}\right)$

\begin{tabular}{|c|c|c|c|c|c|c|}
\hline \multicolumn{4}{|c|}{ G-7 } & \multicolumn{3}{|c|}{ YPE-9 } \\
\hline Değișkenler & CD-LM ${ }_{\text {adj }}$ İst. & Gecikme & Trend & CD-LM ${ }_{\mathrm{adj}}$ İst. & Gecikme & Trend \\
\hline TFP & $37.30 *[0.000]$ & 3 & 1 & $26.09 *[0.000]$ & 5 & 0 \\
\hline GFCF & $35.45 *[0.000]$ & 3 & 1 & $31.60 *[0.000]$ & 5 & 1 \\
\hline EL & $37.44 *[0.000]$ & 3 & 1 & $48.01 *[0.000]$ & 3 & 1 \\
\hline EI & $53.25 *[0.000]$ & 1 & 1 & $62.35 *[0.000]$ & 2 & 0 \\
\hline FDI & $29.31 *[0.000]$ & 4 & 0 & $35.28 *[0.000]$ & 4 & 1 \\
\hline $\mathbf{X M}$ & $25.86 *[0.000]$ & 5 & 1 & $33.60 *[0.001]$ & 4 & 1 \\
\hline HTE & $28.24 *[0.000]$ & 4 & 1 & $55.27 *[0.001]$ & 2 & 1 \\
\hline AR-GE & $27.51 *[0.000]$ & 3 & 1 & $26.72[0.847]$ & 2 & 0 \\
\hline PAT & $38.96 *[0.000]$ & 3 & 1 & $37.26 *[0.000]$ & 4 & 0 \\
\hline Model-1 & $2.85^{*}[0.002]$ & 3 & 1 & $1.64 * * *[0.052]$ & 3 & 1 \\
\hline Model-2 & $3.44 * \quad[0.000]$ & 3 & 1 & $3.04 * \quad[0.001]$ & 3 & 1 \\
\hline Model-3 & $1.14 \quad[0.127]$ & 3 & 1 & $0.510 \quad[0.305]$ & 3 & 1 \\
\hline Model-4 & $3.05 * \quad[0.001]$ & 3 & 1 & $3.02 * \quad[0.001]$ & 3 & 1 \\
\hline Model-5 & $2.86^{*} \quad[0.002]$ & 3 & 1 & $-1.02[0.847]$ & 3 & 1 \\
\hline Model-6 & $3.56^{*} \quad[0.000]$ & 3 & 1 & $1.49 * * *[0.069]$ & 3 & 1 \\
\hline \multicolumn{7}{|c|}{$\begin{array}{l}\text { Not: CD-LM }{ }_{\text {adj }} \text { test istatistik değerlerinin önünde yer alan }\left(^{*}\right),\left({ }^{* *}\right) \text { ve }\left(^{* * *}\right) \text { işaretleri ilgili değişkenlerde ve tanımlanan modellerdeki } \\
\text { eş-bütünleşme denklemlerinde sırasıyla } \% 1, \% 5 \text { ve } \% 10 \text { anlamlılık }(\text { önem) düzeyine göre yatay kesit bağımlılığının olduğunu } \\
\text { göstermektedir. Tablodaki Trend sütununda yer alan "1" rakamı ilgili değişkenin ve modelin sabitli ve trendli formda tahmin edil- } \\
\text { diğini "0" rakamı ise sadece sabitli formda tahmin edildiğini belirtmektedir. Ayrıca, "[ ]" parantez içindeki rakamlar CD-LM }{ }_{\text {adj }}^{\text {test }} \\
\text { istatistik değerlerine ait olasılık (probability) değerlerini göstermektedir. }\end{array}$} \\
\hline
\end{tabular}

Tablo 2'deki CD-LMadj test sonuçları G-7 ve YPE-9 grubundaki modellerin eş-bütünleşme denklemleri açısından incelendiğinde ise elde edilen bulgular şu şekildedir. G-7 grubunda Model-3 ve YPE-9 grubunda ise Model-3 ve Model-5 dişındaki diğer tüm modellerde CD-LM $\mathrm{Ldj}_{\mathrm{j}}$ test istatistiği olasılık değerlerinin 0.01'den küçük olduğu (YPE-9 grubunda Model-1 ve Model-6 için 0.010'dan küçük olduğu) görülmektedir. Bu nedenle, G-7 grubunda Model-3 ve YPE-9 grubunda ise Model-3 ve Model-5 dişındaki diğer tüm modellerde eş-bütünleşme denklemleri için CDLMadj testine göre tanımlanan $\mathrm{H}_{0}$ hipotezlerinin (birimler arasında yatay kesit bağımlılığı yoktur) güçlü bir biçimde reddedilmesi ve alternatif hipotezlerin kabul edilmesi gerekmektedir. Benzer bir şekilde, G-7 grubunda Model-3 ve YPE-9 grubunda ise Model-3 ve Model-5’te ise eş-bütünleşme denklemleri için CD-LMadj testine göre tanımlanan $\mathrm{H}_{0}$ hipotezlerinin (birimler arasında yatay kesit bağımlılığı yoktur) kabul edilmesi ve alternatif hipotezlerin reddedilmesi gerekmektedir. Bu durum, G-7 grubunda Model-3 ve YPE-9 grubunda ise Model-3 ve Model-5 dişındaki tanımlanan diğer tüm modellerde eş-bütünleşme denklemleri açısından yatay kesit bağımlılı̆̆ının bulunduğu anlamına gelmektedir. Tablo 2'deki CDLMadj test sonuçları G-7 ve YPE-9 grubu açısından bir bütün olarak incelendiğinde; G-7 grubu için sadece Model-3 ve YPE-9 grubu için AR-GE değişkeni ile Model-3 ve Model-5 dişındaki diğer tüm değişkenlerde ve eş-bütünleşme denklemlerinde yatay kesit bağımlılı̆̆ının olduğu görülmektedir. Bu sonuçlar, her iki ülke grubundaki ilgili modeller ve değişkenler bir kenara bırakıldığında G-7 ve YPE-9 grubunu oluşturan ülkelerden birinde meydana gelen/gelebilecek bir şoktan diğer ülkelerin de etkilendiğini/etkilenebileceğini göstermektedir. Bu nedenle, bu ülkelerde ikti- 
sadi karar birimlerinin uzun dönemde toplam faktör verimliliği artışı üzerinde etkili olduğu düşünülen belirleyici değişkenlere yönelik politika oluştururken paneli olușturan diğer ülkelerin uyguladıkları politikaları da göz önünde bulundurmalarının gerekli olduğu anlaşılmaktadır. Ayrıca, Tablo 2'deki sonuçlar analizin ilerleyen aşamalarında (G-7 grubu için Model-3, YPE-9 grubu için AR-GE değişkeni ile Model-3 ve Model-5 hariç) tüm değişkenler ve modeller için yatay kesit bağımlılığını göz önünde bulunduran yeni nesil panel veri test yöntemlerinin kullanılmasının gerekli olduğunu ortaya koymaktadır.

\section{Panel Birim Kök Testi Sonuçları ve Değerlendirilmesi}

Yukarıda açıklandığı üzere, panel veri literatüründe birinci kuşak birim kök testleri, paneli oluşturan yatay kesit birimlerde bağımlılığının olmadığı varsayımına dayanmaktadır. Ancak, günümüzde ülkelerin birbirleriyle yakın bir șekilde ilişkili olduğu düşünüldüğünde paneli oluşturan yatay kesit birimlerdeki bağımlılığının varlığını ve ülkelerden birine gelen bir şoktan diğer ülkelerin de farklı düzeylerde etkilendiğini varsaymak daha rasyonel bir yaklaşım olmaktadır. Nitekim panel veri analizindeki bu eksikliği gidermek ve tahmin sonuçlarının etkinliğini artırmak için yatay kesit birimler arasındaki bağımlılığ1 göz önünde bulundurarak durağanlık analizi yapan ikinci nesil birim kök testlerinin kullanılması gerekmektedir (Nazlığlu, 2010, s.4). Başlıca ikinci nesil birim kök testleri arasında Taylor ve Sarno tarafından 1998 yllında geliștirilen MADF (Multivariate Augmented Dickey Fuller) Birim Kök Testi; Breuer ve diğerleri tarafından 2002 yılında geliştirilen SURADF (Seemingly Unrelated Regression Augmented Dickey Fuller) Birim Kök Testi yer almaktadır. Bunların yanında bu çalışmada da kullanılan ve Pesaran tarafından 2007 yllında geliştirilen CADF (Cross-sectional Augmented Dickey Fuller) Birim Kök Testi de en çok kullanılan ikinci nesil birim kök testleri arasında önemli bir yer tutmaktadır.

Pesaran tarafından 2007 yılında geliştirilen ve seriler arasında yatay kesit bağımlılı̆̆ına izin veren ikinci nesil birim kök testi CADF, hem $\mathrm{N}>\mathrm{T}$ durumunda hem de $\mathrm{N}<\mathrm{T}$ durumunda anlamlı sonuçlar vermektedir. Bu teste önce paneli oluşturan tüm birimler için CADF test istatistiği değerleri hesaplanmakta, daha sonra bu testlerin aritmetik ortalaması alınarak panel geneli için CIPS (Cross-Sectionally Augmented IPS) testi istatistiği değerleri hesaplanmaktadır. Bununla beraber, CADF testi sonuçları paneli oluşturan her bir ülke için durağanlık analizi yaparken, CIPS testi sonuçları ise panelin geneli için durağanlık analizi yapmaktadır. Bu kapsamda, CADF test istatistik değerleri aşağıdaki gibi hesaplanmaktadır:

$$
t(N, T)=\frac{\Delta y_{i}^{\prime} \overline{\mathrm{M}}_{i} y_{i-1}}{\bar{\sigma}^{2}\left(\Delta y_{i-1}^{\prime} \overline{\mathrm{M}}_{i} y_{i-1}\right)^{\frac{1}{2}}}
$$

Burada; $\overline{\mathrm{M}}=\left(\tau, \Delta \overline{\mathrm{y}}, \overline{\mathrm{y}}_{t-1}\right)$

Eşitlik 13'teki Tau " $\tau$ " ve diğer değerler ise aşağıdaki gibi tanımlanmaktadır:

$$
\begin{aligned}
& \tau=(1,1, \ldots 1)^{\prime} \\
& \Delta \bar{y}=\left(\Delta \bar{y}_{1}, \Delta \bar{y}_{2}, \ldots \Delta \bar{y}_{t}\right)^{\prime} \\
& \bar{y}_{t-1}=\left(\bar{y}_{0}, \bar{y}_{1}, \ldots \bar{y}_{t-1}\right)^{\prime} \\
& \bar{\sigma}^{2}=\frac{\Delta y_{i}^{\prime} \overline{\mathrm{M}}_{i, w} \Delta y_{i}}{T-4}
\end{aligned}
$$

Birinci denklemde verildiği gibi CADF test istatistiği değerleri hesaplandiktan sonra CIPS istatistik değerleri de aşağıdaki gibi hesaplanmaktadır:

$$
\text { CIPS }=\mathrm{N}^{-1} \sum_{\mathrm{i}=1}^{\mathrm{n}} \mathrm{t}(\mathrm{N}, \mathrm{T})
$$

Burada, CADF ve CIPS test istatistiği değerleri hesaplandıktan sonra testin hipotezleri ise aşağıdaki gibi tanımlanmaktadır:

$$
\begin{aligned}
& \mathrm{H}_{0}=\text { Seride Birim Kök Vardır } \\
& \mathrm{H}_{1}=\text { Seride Birim Kök Yoktur }
\end{aligned}
$$

Elde edilen CADF ve CIPS test istatistiği değerleri Pesaran tarafindan Monte Carlo simülasyonları ile oluşturulan, makalesindeki kritik tablo değerleri ile karşılaştırılmakta ve durağanlık için hipotezler sınanmaktadır. Burada, hesaplanan CADF test istatistik değerinin tablo değerinden büyük olması durumunda $\mathrm{H}_{0}$ temel hipotezi reddedilmekte ve ilgili birim için $\mathrm{H}_{1}$ alternatif hipotezi kabul edilmektedir. Diğer yandan, hesaplanan CIPS test istatistiği değerleri de makaledeki tablo değerleri ile karşılaştırılmakta ve CIPS test istatistik değerlerinin büyük olması durumunda $\mathrm{H}_{0}$ temel hipotezi reddedilmekte ve tüm panel geneli için $\mathrm{H}_{1}$ alternatif hipotezi kabul edilmektedir (Pesaran, 2007, s.265-312). Çalışmada G-7 ve YPE9 ülke grupları için tanımlanan modellerdeki tüm 
değişkenlerde (YPE-9 grubu için AR-GE değişkeni hariç) yatay kesit bağımlılık bulunduğundan, serilerin durağanlık durumu CIPS panel birim kök testiyle incelenmiş ve Pesaran (2007) tarafından hesaplanan kritik tablo değerleri ile birlikte Tablo 3'te sunulmuştur. Bununla birlikte, YPE-9 grubunda AR-GE değișkeni için yatay kesit bağımlılık tespit edilmediğinden bu değişkenin durağanlık durumu ayrıca Levin, Lin ve Chu (1992), Im, Pesaran, ve Shin (2003) birinci nesil panel birim kök testleriyle incelenmiş ve sonuçları Tablo 4'de verilmiştir.

G-7 ve YPE-9 grubu için tanımlanan modellerde kullanılan değişkenlerin istatistik değerlerinin panel geneli için hesaplandığı Tablo 3’teki CIPS sonuçları incelendiğinde, her iki ülke grubunda da bütün değişkenlerin \% 1 anlamlllık düzeyine göre seviye düzeyinde $[\mathrm{I}(0)]$ durağan olmadıkları görülmektedir. $\mathrm{Bu}$ durum, değişkenler için sabitli veya sabitli ve trendli formlarda hesaplanan CIPS istatistik değerlerinin kritik tablo değerlerinden 0.01 önem düzeyinde mutlak değer olarak küçük olmasından anlaşılmaktadır. Bu nedenle, her iki ülke grubunda da serilerin birinci farklarının alınması yoluna gidilmiş ve değişkenlerin birinci farkları alındığında [I(1)] tüm değişkenlerin \% 1 önem düzeyine göre durağanlaştığ 1 tespit edilmiştir. Bu durum, değişkenler için sabitli veya sabitli ve trendli formlarda hesaplanan CIPS istatistik değerlerinin kritik tablo değerlerinden 0.01 önem düzeyinde mutlak değer olarak büyük olmasından anlaşılmaktadır.

YPE-9 grubunda AR-GE değişkeni için birinci nesil LLC ve IPS panel birim kök testi sonuçlarının yer aldığ 1 Tablo 4 incelendiğinde; AR-GE değişkeninin her iki test istatistiğine göre sabitli veya sabitli ve trendli formda seviye düzeyinde [I(0)] durağan olmadığ görülmektedir. $\mathrm{Bu}$ durum, AR-GE değişkeni için hesaplanan test istatistiklerinin olasıllk değerlerinin 0.01 'den büyük olmasından anlaşılmaktadır. Bu nedenle, AR-GE değişkeni için birinci farklarının alınması yoluna gidilmiş ve değişkenin birinci farkı alındığında [I(1)] hem LLC hem de IPS testlerine göre \% 1 önem düzeyine göre durağanlaştı̆̆ tespit edilmiştir. $\mathrm{Bu}$ durum, AR-GE değişkeni için hesaplanan test istatistiklerinin olasılık değerlerinin 0.01 'den küçük olmasından anlaşılmaktadır.

Tablo 3. CADF Panel Birim Kök Testi Sonuçları

\begin{tabular}{|c|c|c|c|c|c|c|}
\hline & & \multicolumn{4}{|c|}{ Panel Geneli (CIPS) İstatistikleri } & \multirow{2}{*}{$\begin{array}{c}\text { CIPS Kritik Tablo Değeri } \\
(\mathbf{0 . 0 1})\end{array}$} \\
\hline \multicolumn{2}{|c|}{ Değişkenler } & Seviye & 1. Fark & Gecikme & Trend & \\
\hline \multirow{9}{*}{ G-7 } & TFP & -2.55 & $-4.07 *$ & 3 & 1 & -3.15 \\
\hline & GFCF & -2.80 & $-3.92 *$ & 3 & 1 & -3.15 \\
\hline & EL & -2.90 & $-3,23^{*}$ & 3 & 1 & -3.15 \\
\hline & EI & -2.17 & $-3.71 *$ & 1 & 1 & -3.15 \\
\hline & FDI & -2.22 & $-3.57 *$ & 4 & 0 & -2.60 \\
\hline & $\mathbf{X M}$ & -2.54 & $-4.19^{*}$ & 5 & 1 & -3.15 \\
\hline & HTE & -3.08 & $-4.31 *$ & 4 & 1 & -3.15 \\
\hline & AR-GE & -2.75 & $-3.57 *$ & 3 & 1 & -3.15 \\
\hline & PAT & -2.75 & $-4.96^{*}$ & 3 & 1 & -3.15 \\
\hline \multirow{9}{*}{ YPE-9 } & TFP & -2.11 & $-3.56^{*}$ & 5 & 0 & -2.60 \\
\hline & GFCF & -2.85 & $3.76^{*}$ & 5 & 1 & -3.15 \\
\hline & EL & -2.02 & $-3.28 *$ & 3 & 1 & -3.15 \\
\hline & EI & -1.56 & $-3.08^{*}$ & 2 & 0 & -2.60 \\
\hline & FDI & -2.50 & $-3.34 *$ & 4 & 1 & -3.15 \\
\hline & $\mathbf{X M}$ & -2.80 & $-3.62 *$ & 4 & 1 & -3.15 \\
\hline & HTE & -2.79 & $-3.52 *$ & 2 & 1 & -3.15 \\
\hline & AR-GE & -2.16 & $-3.00 *$ & 2 & 0 & -2.60 \\
\hline & PAT & -2.29 & $-3.70 *$ & 4 & 0 & -2.60 \\
\hline
\end{tabular}

Not: CIPS istatistiklerinin önünde yer alan $\left(^{*}\right)$ ișareti değișkenlerin $\% 1$ anlamlılık düzeyinde durağan olduklarını göstermektedir. CADF ve CIPS testlerinde optimal gecikme uzunlukları Schwarz bilgi kriterine göre belirlenmiş ve CIPS istatistiği kritik tablo değerleri T ve N spesifikasyonuna uygun olarak Pesaran (2007) çalışmasından alınmıştır. Tablodaki Trend sütununda yer alan "1" rakamı ilgili değișkenin sabitli ve trendli formda tahmin edildiğini "0" rakamı ise sadece sabitli formda tahmin edildiğini belirtmektedir. 
Tablo 4. LLC ve IPS Panel Birim Kök Testi Sonuçları

\begin{tabular}{|c|c|c|c|}
\hline \multicolumn{4}{|c|}{ YPE-9 } \\
\hline AR-GE & Seviye & 1. Fark & Trend \\
\hline Levin, Lin \& Chu T-İst. & $-0.574[0.283]$ & $-7.694 *[0.000]$ & 1 \\
\hline Im, Pesaran \& Shin W-İst. & $-0.575[0.283]$ & $-3.512 *[0.002]$ & 0 \\
\hline
\end{tabular}

Not: $\left.{ }^{*}\right)$ işareti değişkenin \% 1 önem düzeyinde durağan olduğunu belirtmektedir. Testlerde hatalar arasındaki otokorelasyon sorununu gideren uygun gecikme uzunlukları Schwarz bilgi kriterine göre otomatik olarak seçilmiştir. LLC testinde Bartlett Kernel metodu kullanılmış ve Bandwidth genişliği Newey-West yöntemi ile belirlenmiştir. Ayrıca, Tablo 2'deki açıklamalara bakınız.

Tablo 3 ve Tablo 4'de yer alan panel birim kök testi sonuçları bir bütün olarak düşünüldüğünde, G-7 ve YPE-9 grubunda toplam faktör verimliliğinin belirleyicilerini tespit etmek üzere tanımlanan modellerde kullanılan bütün değişkenlerin seviye değerinde durağan olmadıkları, ancak birinci farkları [I(1)] alındığında durağanlaştıkları tespit edilmiştir.

\section{Panel Eş-Bütünleşme Testi Sonuçları ve Değerlendirilmesi}

Seviye düzeyinde durağan olmayan, ancak farkları alınarak durağanlaştırılan serilerde, bu fark alma işlemi serilerinin geçmiş süreçte maruz kaldığı geçici şokların etkisini yok ettiği gibi aynı zamanda bu seriler arasında olması muhtemel uzun dönemli ilişkileri de ortadan kaldırabilmektedir. Bu nedenle durağanlaştırılmıș veriler ile kurulan bir model, değișkenler arasındaki olması muhtemel uzun dönemli ilişkiyi de tam olarak yansitamayabilir. Böyle bir durumda iktisadi değişkenlere ait seriler durağan olmasalar bile bu serilerin durağan bir kombinasyonu var olabilir ve eğer varsa bu eş-bütünleşme analizi ile belirlenebilir (Tarı, 2010, s.415). Bu doğrultuda eş-bütünleşme, basitçe iki veya daha fazla durağan dışı değişken arasında durağan bir ilișkinin elde edilmesini sağlayan süreç olarak tanımlanabilmektedir. Eş- bütünleșme analizleri ile durağan dışı değişkenlerin aralarında uzun dönemli birlikte hareket ettikleri bir denge ilişkisinin ortaya konulabildiği belirtilmektedir (Sevüktekin ve Çınar, 2014, s.559). Eş-bütünleşme analizine göre $\mathrm{I}(0)$ da durağan olmayan $\left(X_{t}\right)$ ve $\left(Y_{t}\right)$ gibi iki değişkenin herhangi bir I(d) noktasında durağan olması durumunda doğrusal birleşimi durağan olabilmektedir. Bu durum aşağıdaki gibi gösterebilir;

$$
\begin{aligned}
& X_{t}=b_{1}+b_{2} Y+u_{t} \\
& u_{t}=X_{t}-b_{1-} b_{2} Y_{t}
\end{aligned}
$$

Eşitlik 20'deki denklemde $\left(u_{t}\right)$ yani $\left(X_{t}-b_{1-} b_{2} Y_{t}\right)$ 'nin doğrusal bileşiminin $\mathrm{I}(0)$ da durağan olduğu tespit edilebilirse $\left(X_{t}\right)$ ve $\left(Y_{t}\right)$ değişkenlerinin eş-bütünleşik olduğu da söylenebilir (Gujarati, 2009, s.726).

Tanımlanan modellerde kullanılan değişkenlerde yatay kesit bağımlılı̆̆ı ve durağanlık analizleri yapıldıktan sonra elde edilen bilgiler doğrultusunda uygulanacak olan eş-bütünleşme testlerine karar verilmesi gerekmektedir. Zira panel veri çalışmalarında yatay kesit bağımsızlığını dikkate almayan (Kao, 1999; Pedroni, 1999) vb. eş-bütünleşme testleri oldukça yaygın bir biçimde kullanılmakla birlikte serilerde ve eşbütünleşme denkleminde yatay kesit bağımlılığının olması durumunda bu testlerin güvenilir sonuçlar vermeyeceği belirtilmektedir. Böyle bir durumda değişkenler arasında yatay kesit bağımlılı̆̆ına izin veren yeni nesil panel eş-bütünleşme testlerinin kullanılması önerilmektedir. Çalışmada TFP’nin belirleyicilerini tespit etmek üzere tanımlanan bütün modellerde (G-7 grubu için Model-3, YPE-9 grubu için Model-3 ve Model-5 hariç) yatay kesit bağımlılığ edildiğinden, modellerdeki serilerin uzun dönemde eş-bütünleşik olup olmadıkları YKB'yi dikkate alan Westerlund-Edgerton (2007) Panel Eş-Bütünleşme Testiyle incelenecektir. Bununla beraber G-7 grubunda Model-3 ve YPE-9 grubunda ise Model-3 ile Model-5'te yatay kesit bağımlılı̆̆ bulunmadığından, bu modellerdeki serilerin uzun dönemde eşbütünleşik olup olmadıkları YKB'yi dikkate almayan Kao Panel Eş-Bütünleşme Testi ile araştırılacaktır.

Westerlund-Edgerton (2007) Panel Eş-Bütünleşme testinde temel hipotez değişkenler arasında eşbütünleşme ilişkisinin bulunduğunu belirten LM test istatistiği ile araştırılmaktadır. Bu teste panel için hesaplanan LM test istatistikleri sağ taraflı standart normal dağılım göstermekte ve $\% 5$ anlamlılık düzeyinde 
(1.645) kritik değeri temel ve alternatif hipotezlerin sınanması için kullanılmaktadır. Bu bağlamda, LM istatistiklerine göre hesaplanan eş-bütünleşme test istatistikleri 1.645 kritik tablo değerinden büyükse temel hipotez (yatay kesit seriler arasında eş-bütünleşme ilişkisi vardır) kabul edilmekte ve alternatif hipotez (yatay kesit seriler arasında eş-bütünleşme ilişkisi yoktur) reddedilmektedir (Westerlund and Edgerton, 2007, s.185-190). Böylelikle tanımlanan modelde yer alan değişkenler arasında uzun dönemli bir eşbütünleşme ilişkisinin olduğuna karar verilmektedir. Bu kapsamda, G-7 ve YPE-9 grubunda tanımlanan modellerde yer alan değiş̧enler arasındaki uzun dönemli eş-bütünleşme ilişkilerinin varlığı WesterlundEdgerton (2007) ve Kao Panel Eş-Bütünleşme testleriyle ile incelenerek sonuçları Tablo 5 ve Tablo 6'da sunulmuştur.

Tablo 5. Westerlund-Edgerton (2007) Panel Eş-Bütünleşme Test Sonuçları

\begin{tabular}{|c|c|c|c|c|c|}
\hline \multicolumn{5}{|c|}{ G-7 } \\
\hline LM & Model-1 & Model-2 & Model-4 & Model-5 & Model-6 \\
\hline Test-İstatistiği & $6.680^{*}$ & $5.721^{*}$ & $6.191^{*}$ & $4.892^{*}$ & $5.428^{*}$ \\
\hline Bootstrap Olasılık & {$[0.549]$} & {$[0.849]$} & {$[0.737]$} & {$[0.981]$} & {$[0.901]$} \\
\hline & & YPE-9 \\
\hline LM & Model-1 & Model-2 & Model-4 & Model-6 & \\
\hline Test-İstatistiği & $7.356^{*}$ & $7.113^{*}$ & $7.295^{*}$ & $7.060^{*}$ \\
\hline Bootstrap Olasılık & {$[0.773]$} & {$[0.700]$} & {$[0.587]$} & {$[0.846]$} & \\
\hline
\end{tabular}

Not: LM test istatistiklerinin önünde yer alan $\left.{ }^{*}\right)$ ișareti $\% 1$ anlamlllı düzeyine göre ilgili modeldeki seriler arasında eș-bütünleșme ilişkisinin olduğu anlamına gelmektedir. Westerlund-Edgerton (2007) testleri için rapor edilen olasilık değerleri yatay kesit bağımlılığını dikkate alan 10.000 tekrarlı bootstrap dağılımından ve test istatistikleri de sabitli ve trendli formdan elde edilmiştir. Ayrıca "[ ]" parantez içindeki rakamlar LM test istatistik değerlerine ait olasllık (probability) değerlerini göstermektedir.

G-7 ve YPE-9 grubunda tanımlanan modellerde kullanılan değişkenler arasındaki uzun dönemli ilişkileri araştıran Westerlund-Edgerton test sonuçları incelendiğinde; her iki ülke grubunda bütün modellerde $\mathrm{H}_{0}$ temel hipotezinin (yatay kesit seriler arasında eşbütünleşme ilişkisi vardır) kabul edildiği ve $\mathrm{H}_{1}$ alternatif hipotezinin \% 1 önem düzeyinde reddedildiği görülmektedir. $\mathrm{Bu}$ durum, tanımlanan modeller için hesaplanan LM test istatistik değerlerinin 1.645 kritik tablo değerlerinden büyük olmasından anlaşılmak- tadır. Benzer bir şekilde, G-7 ve YPE-9 gruplarında YKB'nin olmadığı modellerde uzun dönemli ilişkileri araştıran Tablo 6'daki Kao Panel Eş-Bütünleşme test sonuçları incelendiğinde, bütün modellerde $\mathrm{H}_{0}$ temel hipotezinin (seriler arasında eş-bütünleşme yoktur) reddedildiği ve değişkenlerin eş-bütünleşik olduğunu belirten $\mathrm{H}_{1}$ alternatif hipotezinin kabul edildiği görülmektedir. Bu durum, tanımlanan bütün modeller için hesaplanan ADF t-istatistiklerine ait olasılık değerlerinin 0.01'den küçük olmasından anlaşılmaktadır.

Tablo 6. Kao Panel Eş-Bütünleşme Test Sonuçları

G-7

\begin{tabular}{|c|c|c|}
\hline \multirow{2}{*}{ Model-3 } & Kao Panel Eş-Bütünleşme Testi & t-İstatistiği \\
\hline \multirow{2}{*}{ Model-3 } & ADF & $-3.049^{*}[0.000]$ \\
\hline \multirow{2}{*}{ Model-5 } & YPE-9 & t-İstatistiği \\
\hline & Kao Panel Eş-Bütünleşme Testi & $-5.065^{*}[0.000]$ \\
\hline & ADF & t-İstatistiği \\
\hline
\end{tabular}

Not: ADF test istatistiklerinin önünde yer alan $\left(^{*}\right)$ işareti $\% 1$ anlamlılık düzeyine göre ilgili modeldeki seriler arasında eşbütünleşme ilişkisinin olduğu anlamına gelmektedir. Kao Eş-Bütünleşme Testinde gecikme uzunlukları Schwarz bilgi kriterine göre tespit edilerek, Bartlett Kernel metodu kullanılmıș ve Bandwidth genișliği Newey-West yöntemi ile belirlenmiștir. Ayrıca, "[ ]” parantez içindeki rakamlar ADF test istatistiklerine ait olasılık (probability) değerlerini göstermektedir. 
Panel Eş-Bütünleşme test sonuçları bir bütün olarak düşünüldüğünde, G-7 ve YPE-9 ülke gruplarında toplam faktör verimliliğinin belirleyicilerini tespit etmek üzere tanımlanan istisnasız bütün modellerde uzun dönemde güçlü bir eş-bütünleşme ilişkisinin, diğer bir deyişle birlikte hareketin söz konusu olduğu ve değişkenlerin uzun dönemde benzer trendleri takip etme eğiliminde oldukları rahatlıkla söylenebilmektedir.

\section{Panel DSUR ile Uzun Dönem Eş-Bütünleşme Katsayıların Tahmini ve Değerlendirilmesi}

Toplam faktör verimliliğinin belirleyicilerini tespit etmek üzere tanımlanan bütün modellerde yer alan değişkenler arasındaki uzun dönemli ilişkiler eş-bütünleşme testleri ile belirlendikten sonra bağımsız değişkenlere ait uzun dönem katsayılarının nasıl tahmin edileceği sorunu ortaya çıkmaktadır. Bu kapsamda, çalışmada tanımlanan bütün modellerde (G-7 grubu için Model-3, YPE-9 grubu için Model-3 ve Model-5 hariç) yatay kesit bağımlılı̆̆ı tespit edildiğinden ilgili bağımsız değişkenlerin, TFP bağımlı değişkeni üzerindeki uzun dönemli etkilerinin yönünün ve büyüklüğünün YKB’yi dikkate alan tahmincilerle belirlenmesi gerekmektedir. Bu noktada, G-7 ve YPE-9 grubunda YKB'nin bulunduğu modellerde GFCF, EL, EI, FDI, HTE, AR-GE ve PAT bağımsız değişkenlerinin TFP bağımlı değişkeni üzerindeki uzun dönemli etkilerinin yönünün ve büyüklüğ̈̈nün, YKB’yi göz önünde bulundurun DSUR (Dynamic Seemingly Unrelated Cointegrating Regressions) Görünüşte ilişkisiz Dinamik Eş-Bütünleşme Regresyonu yöntemi ile tahmin edilmesi yoluna gidilecektir. Park ve Ogaki (1991) tarafından geliştirilen SUR (Seemingly Unrelated Cointegrating Regressions) modelinin parametrik olmayan tahmincilerinin parametrik bir alternatifi olarak geliştirilen DSUR yönteminin, parametrik varsayımların doğru olduğu durumlarda SUR yöntemine kıyasla daha etkili sonuçlar üretebileceği kabul edilmektedir. Mark vd., (2005) tarafından geliştirilen DSUR yöntemi, modeldeki çoklu eş-bütünleşik regresyonları parametrik bir yöntemle tahmin etmekte ve denklemler arasindaki eş-bütünleşik vektörlerin homojen veya heterojen olduğu durumlarda da kullanılabilmektedir. Diğer yandan DSUR yöntemi, zaman boyutunun yatay kesit boyutundan büyük olduğu durumlarda daha tutarlı ve asimtotik olarak normal dağılım sağlayan sonuçlar üretebilmekle birlikte zaman boyutunun yatay kesit boyutundan küçük olduğu durumlarda kullanılabilmektedir (Mark vd., 2005, s.797-820).

Bununla birlikte, G-7 (Model-3) ve YPE-9 (Model-3, Model-5) grubunda YKB'nin bulunmadığı modellerde GFCF, EL, XM ve AR-GE bağımsız değişkenlerinin TFP bağımlı değişkeni üzerindeki uzun dönemli etkilerinin yönünün ve büyüklüğünün DOLS (Dynamic Ordinary Least Squares) Dinamik En Küçük Kareler yöntemi ile tahmin edilmesi yoluna gidilecektir. DOLS yönteminin modele dinamik unsurları dâhil ederek statik regresyondaki özellikle içsellikten kaynaklanan sapmaları giderdiği ve daha tutarlı sonuçların elde edilmesine olanak sağladığı kabul edilmektedir. Çalışmada G-7 ve YPE-9 grubunda toplam faktör verimliliğinin belirleyicilerini tespit etmek üzere kurulan modellerden YKB'nin bulunduğu modeller DSUR ile YKB'nin bulunmadığı modeller ise DOLS tahmin edilmiş ve elde edilen sonuçlar Tablo 7'de sunulmuştur.

Tablo 7'deki tahmin sonuçları G-7 grubu paneli açısindan incelendiğinde, beklentilerle uyumlu olarak GFCF, EI, FDI, XM, HTE, AR-GE ve PAT açıklayıc1 değişkenlerinin katsayılarının pozitif ve (FDI değişkeni dışında) istatistiki olarak \% 1 ile \% 5 önem düzeyinde anlamlı olduğu sonucuna ulaşılmıştır. $\mathrm{Bu}$ sonuçlar çalışma dönemde, sabit sermaye yatırımlar1, aktif nüfusun eğitim seviyesi, doğrudan yabanc1 yatırımlar, ülkelerin dışa açılma dereceleri, yüksek teknoloji ihracatı, araştırma-geliştirme yatırımları ve patent başvuru sayısında meydana gelen artışların/ iyileşmelerin sürdürülebilir ekonomik büyümenin temelini oluşturan TFP artışına panelin tümünde pozitif ve genellikle anlamlı bir şekilde katkı sağladığını ortaya koymaktadır. Buna karşılık, EL açılkayıcı değişkeninin katsayısının ise istinasız tüm modellerde negatif ve istatistiki olarak \% 1 önem düzeyinde anlamlı olduğu belirlenmiştir. Bu durum, G-7 grubunda istihdam edilen işgücü sayısında meydana gelen bir artışın beklentilerle uyumlu olarak toplam faktör verimliliğini azaltıcı yönde bir etkiye sahip olduğunu göstermektedir. 
Tablo 7. Uzun Dönemli Eş-Bütünleşme Katsayıları: Panel DSUR-DOLS Sonuçları

\begin{tabular}{|c|c|c|c|c|c|c|}
\hline \multicolumn{7}{|c|}{ Bağımlı Değişken: TFP } \\
\hline \multicolumn{4}{|c|}{ G-7 } & \multicolumn{3}{|c|}{ YPE-9 } \\
\hline \multirow[b]{2}{*}{ Model-1 } & GFCF & $\mathbf{E L}$ & EI & GFCF & $\mathbf{E L}$ & EI \\
\hline & $\begin{array}{l}\text { 0.175* } \\
(0.021) \\
{[0.000]}\end{array}$ & $\begin{array}{l}\mathbf{- 0 . 3 5 3 *} \\
(0.091) \\
{[0.000]}\end{array}$ & $\begin{array}{l}\mathbf{0 . 3 3 8 *} \\
(0.100) \\
{[0.001]}\end{array}$ & $\begin{array}{l}\mathbf{0 . 2 5 4} * \\
(0.016) \\
{[0.000]}\end{array}$ & $\begin{array}{l}-\mathbf{0 . 2 7 3} * \\
(0.085) \\
{[0.001]}\end{array}$ & $\begin{array}{c}\mathbf{0 . 0 0 7} \\
(0.303) \\
{[0.982]}\end{array}$ \\
\hline \multirow[b]{2}{*}{ Model-2 } & GFCF & EL & FDI & GFCF & $\mathbf{E L}$ & FDI \\
\hline & $\begin{array}{c}\mathbf{0 . 1 6 9 *} \\
(0.0214) \\
{[0.000]}\end{array}$ & $\begin{array}{c}\mathbf{- 0 . 2 7 5 *} \\
(0.091) \\
{[0.003]}\end{array}$ & $\begin{array}{l}\mathbf{4 . 6 2 0} \\
(0.000) \\
{[0.809]}\end{array}$ & $\begin{array}{l}\text { 0.241* } \\
(0.016) \\
{[0.000]}\end{array}$ & $\begin{array}{c}\mathbf{- 0 . 3 9 7} \text { * } \\
(0.072) \\
{[0.000]}\end{array}$ & $\begin{array}{c}\mathbf{0 . 0 0 2} \\
(0.004) \\
{[0.573]}\end{array}$ \\
\hline \multirow[b]{2}{*}{ Model-3 ${ }^{\text {DOLS }}$} & GFCF $^{\text {DOLS }}$ & $\mathbf{E L}^{\text {DOLS }}$ & $\mathbf{X} \mathbf{M}^{\text {DOLS }}$ & GFCF $^{\text {DOLS }}$ & $\mathbf{E L}^{\text {DOLS }}$ & $\mathbf{X} \mathbf{M}^{\text {DOLS }}$ \\
\hline & $\begin{array}{c}\mathbf{0 . 0 8 9} * * \\
(0.039) \\
{[0.025]}\end{array}$ & $\begin{array}{l}\mathbf{- 0 . 4 5 2 *} \\
(0.153) \\
{[0.004]}\end{array}$ & $\begin{array}{l}\text { 0.167* } \\
(0.039) \\
{[0.000]}\end{array}$ & $\begin{array}{l}\text { 0.279* } \\
(0.035) \\
{[0.000]}\end{array}$ & $\begin{array}{c}\mathbf{- 0 . 3 3 3} * * * \\
(0.176) \\
{[0.062]}\end{array}$ & $\begin{array}{c}\mathbf{0 . 0 4 9} \\
(0.057) \\
{[0.388]}\end{array}$ \\
\hline \multirow[b]{2}{*}{ Model-4 } & GFCF & $\mathbf{E L}$ & HTE & GFCF & $\mathbf{E L}$ & HTE \\
\hline & $\begin{array}{l}\text { 0.148* } \\
(0.021) \\
{[0.000]}\end{array}$ & $\begin{array}{l}\mathbf{- 0 . 2 9 3 *} \\
(0.086) \\
{[0.001]}\end{array}$ & $\begin{array}{l}\text { 0.026* } \\
(0.006) \\
{[0.000]}\end{array}$ & $\begin{array}{l}\text { 0.239* } \\
(0.016) \\
{[0.000]}\end{array}$ & $\begin{array}{l}-\mathbf{0 . 4 1 9 *} \\
(0.071) \\
{[0.000]}\end{array}$ & $\begin{array}{c}\mathbf{0 . 0 0 5} * * * \\
(0.003) \\
{[0.097]}\end{array}$ \\
\hline \multirow[b]{2}{*}{ Model-5 $5^{\text {DOLS }}$} & GFCF & EL & AR-GE & GFCF $^{\text {DOLS }}$ & $\mathbf{E L}^{\text {DOLS }}$ & AR-GE ${ }^{\text {DOLS }}$ \\
\hline & $\begin{array}{l}\text { 0.174* } \\
(0.021) \\
{[0.000]}\end{array}$ & $\begin{array}{l}\mathbf{- 0 . 3 7 9 *} \\
(0.097) \\
{[0.000]}\end{array}$ & $\begin{array}{l}\text { 0.055* } \\
(0.021) \\
{[0.009]}\end{array}$ & $\begin{array}{l}\text { 0.269* } \\
(0.017) \\
{[0.000]}\end{array}$ & $\begin{array}{l}\mathbf{- 0 . 0 8 5} \\
(0.092) \\
{[0.396]}\end{array}$ & $\begin{array}{c}\mathbf{0 . 0 8 5} \\
(0.163) \\
{[0.601]}\end{array}$ \\
\hline \multirow[b]{2}{*}{ Model-6 } & GFCF & $\mathbf{E L}$ & PAT & GFCF & $\mathbf{E L}$ & PAT \\
\hline & $\begin{array}{l}\text { 0.173* } \\
(0.021) \\
{[0.000]}\end{array}$ & $\begin{array}{c}-\mathbf{- 0 . 3 8 6 *} \\
(0.096) \\
{[0.000]}\end{array}$ & $\begin{array}{l}\text { 0.016* } \\
(0.005) \\
{[0.005]}\end{array}$ & $\begin{array}{l}\mathbf{0 . 2 5 5 *} \\
(0.016) \\
{[0.000]}\end{array}$ & $\begin{array}{l}-\mathbf{- 0 . 2 7 9 *} \\
(0.086) \\
{[0.001]}\end{array}$ & $\begin{array}{c}\mathbf{0 . 0 1 8} \\
(0.051) \\
{[0.657]}\end{array}$ \\
\hline
\end{tabular}

Not: Modellerin ve değişkenlerin üzerinde yer alan DOLS işareti ilgili modellerin (YKB bulunmadığından) DOLS yöntemi ile tahmin edildiğini belirtmektedir. Modellerde değişkenler için hesaplanan katsayıların önünde bulunan $\left(^{*}\right),\left({ }^{* *}\right)$ ve $\left(^{* * *}\right)$ ișaretleri katsayılara ait t-istatistiklerinin sırasıyla \% 1, \% 5 ve \% 10 önem düzeyine göre anlamlı olduğunu göstermektedir. "[ ]” parantez içindeki rakamlar katsayılara ait olasılık (probability) değerlerini, "( )” parantez içindeki rakamlar ise katsayılara ait standart hataları göstermektedir.

Tablo 7'deki tahmin sonuçları YPE-9 grubu paneli açısından incelendiğinde, beklentilerle uyumlu olarak bütün modellerde GFCF açıklayıcı değişkeninin katsayısının pozitif ve istatistiki olarak \% 1 önem düzeyinde anlamlı olduğu, buna karşılık EL açıklayıcı değişkeninin katsayısının ise negatif ve istatistiki olarak farklı önem düzeylerinde genellikle anlamlı olduğu belirlenmiştir. Bu sonuçlar inceleme dönemde, sabit sermaye yatırımlarında meydana gelen artışların/iyileşmelerin sürdürülebilir ekonomik büyümenin temelini oluşturan TFP artışına panel genelinde pozitif ve anlamlı bir şekilde katkı sağlad1ğını, istihdam edilen işgücü sayısında meydana gelen artışların ise toplam faktör verimliliğini azalttığını ortaya koymaktadır. Diğer taraftan, YPE-9 grubu için tanımlanan modellerde TFP'nin belirleyicisi olarak kullanılan bilgi, inovasyon ve teknolojik gelişme göstergelerinden; EI, FDI, XM, AR-GE ve PAT açıklayıcı değişkenlerinin katsayılarının pozitif olduğu ancak $\% 10$ önem düzeyinde bile anlamlı olmadıkları tespit edilmiştir. Bununla beraber, tanımlanan modellerde bilgi, inovasyon ve teknolojik gelişme göstergesi olarak sadece HTE açıklayıcı değişkeninin katsayısının pozitif ve istatistiki olarak $\% 10$ önem düzeyinde anlamlı olduğu sonucuna ulaşılmıştır. Bu sonuçlar çalışma dönemde, G-7 grubunun aksine YPE-9 grubunda aktif nüfusun eğitim seviyesi, ülkelerin dışa açılma dereceleri, araştırma-geliştirme yatırımları ve patent başvurularının sürdürülebilir ekonomik büyümenin temelini oluşturan TFP artışı üzerinde önemli bir etkisinin olmadığını göstermektedir. 
Toplam faktör verimliliğinin belirleyicilerini tespit etmek üzere G-7 ve YPE-9 grubu için tanımlanan modellerden elde edilen bulgular bir bütün olarak değerlendirildiğinde ise teorik ve ampirik literatürle uyumlu olduğu belirlenen sonuçları şu şekilde özetlemek mümkün olmaktadır. Bu kapsamda, G-7 ve YPE-9 gruplarında tanımlanan bütün modellerde sabit sermaye yatırımları (GFCF) değişkeninin toplam faktör verimliliği üzerindeki etkisinin pozitif ve istatistiki olarak anlamlı olduğu ve bu pozitif yönlü etkinin büyüklüğünün ise beklenildiği gibi YPE-9 grubunda daha fazla olduğu sonucuna ulaşılmıştır. Dahası YPE-9 grubunda G-7 grubuna kiyasla sabit sermaye yatırımları değişkeninin TFP üzerindeki pozitif yönlü etkisinin büyüklügünün bazı modellerde (örneğin Model-3) üç kattan daha fazla olduğu Tablo 7'deki sonuçlardan görülmektedir. G-7 ve YPE-9 gruplarında tanımlanan istisnasız bütün modellerde istihdam edilen işgücünün (EL), toplam faktör verimliliğini azaltıcı yönde bir etkiye sahip olduğu ve bu etkinin iki ülke grubu arasında ayırt edici derecede farlılıklar oluşturmadığı sonucuna ulaşılmıştır. Bununla birlikte iki ülke grubu arasında uzun dönemde toplam faktör verimliliği artışı üzerinde fark yaratan asıl unsurların ise ülkelerin bilgi, inovasyon ve teknolojik gelişmişlik seviyelerini temsilen kullanılan EI, FDI, XM, HTE, AR-GE ve PAT şeklindeki değişkenlerde olduğu tespit edilmiştir.

Nitekim Tablo 7'deki Model-1 sonuçları G-7 ve YPE9 grupları açısından incelendiğinde, aktif nüfusun eğitim seviyesini gösteren (EI) eğitim değişkeninin TFP üzerindeki etkisinin her iki ülke grubunda pozitif yönlü olduğu ancak bu pozitif yönlü etkinin YPE-9 grubunda istatistiki açıdan anlamsız olduğu belirlenmiştir. Üstelik G-7 grubunda YPE-9 grubuna kıyasla istatistiki açıdan anlamlı olduğu belirlenen eğitim değişkeninin TFP üzerindeki pozitif yönlü etkisinin büyüklüğünün kat ve kat daha fazla olduğu da Tablo 7'deki Model-1 sonuçlarından izlenmektedir. Benzer bir şekilde, XM değişkeninin yer aldığı Model-3'ün sonuçları incelendiğinde, ülkelerin dış dünyaya açılma derecelerinin TFP üzerindeki etkisinin her iki ülke grubunda pozitif yönlü olduğu ancak bu pozitif yönlü etkinin YPE-9 grubunda istatistiki açıdan anlamsız olduğu belirlenmiştir. Dahası G-7 grubunda YPE-9 grubuna kıyasla istatistiki açıdan anlamlı olduğu belirlenen XM değişkeninin TFP üzerindeki pozitif yönlü etkisinin büyüklügünün yaklaşı üç kat daha fazla olduğu yine Tablo 7'deki sonuçlardan görülmektedir. Bu sonuçlar G-7 grubunda diş ticaret hacminin hem niceliksel hem de niteliksel açıdan daha iyi bir seviyede olduğu çıkarımının yapılabilmesine olanak tanımaktadır. Zira G-7 ve YPE-9 gruplarında ihracatın kalitesini yansıtan yüksek teknoloji ihracatı değişkeninin (HTE) toplam faktör verimliliği üzerindeki etkisinin araştırıldığ 1 Tablo 7'deki Model4’ün bulguları da bu durumu teyit eder niteliktedir. Model-4'ün sonuçları incelendiğinde, her iki ülke grubunda yüksek teknoloji ihracatının toplam faktör verimliliği üzerindeki etkisinin pozitif ve anlamlı olduğu ve etkinin büyüklüğünün G-7 grubunda YPE-9 grubuna kıyasla yaklaşık beş kat daha fazla olduğu görülmektedir.

Doğrudan yabancı yatırımların açıklayıcı değişken olarak yer aldığı Model-3'ün bulguları incelendiğinde ise her iki ülke grubunda FDI değişkeninin toplam faktör verimliliği üzerindeki etkisinin pozitif ancak istatistiki açıdan anlamsız olduğu belirlenmiştir. Bununla beraber, doğrudan yabancı yatırımlarının TFP üzerindeki etkisinin büyüklügünün beklenildiği gibi G-7 grubunda çok daha fazla olduğu sonucuna ulaşılmıştır. Son olarak, araştırma-geliştirme yatırımları ve patent başvuru sayılarının TFP üzerindeki etkilerinin araştırıldığ 1 modellerin bulguları incelendiğinde, G-7 ve YPE-9 grubunda AR-GE ile PAT değişkenlerinin toplam faktör verimliliği üzerindeki etkilerinin pozitif yönlü ve benzer büyüklükte oldukları görülmektedir. Buna karşılık AR-GE ve PAT değişkenlerinin G-7 grubundaki modellerde istatistiki açıdan anlamlı olduğu, ancak YPE-9 grubundaki modellerde istatistiki açıdan anlamlı olmadıkları Tablo 7'deki sonuçlardan izlenmektedir.

Özetle, toplam faktör verimliliğinin uzun vadeli belirleyicilerini tespit etmek üzere tanımlanan modellerin bulguları G-7 grubunda TFP'nin belirleyicilerinin sırasıyla, aktif nüfusun eğitim seviyesi, ülkelerin dışa açıklık derecesi, sabit sermaye yatırımları, araştırmageliştirme yatırımları, yüksek teknoloji ihracatı ve patent başvuru sayıları şeklinde olduğunu göstermektedir. Buna karşıllk, YPE-9 grubunda toplam faktör verimliliğinin belirleyicileri arasında sadece sabit sermaye yatırımlarının ve yüksek teknoloji ihracatının yer aldığ 1 görülmektedir. Tanımlanan modellerden elde edilen tüm bu sonuçlar özellikle bilgi, inovasyon ve teknolojik gelişmişlik göstergeleri (EI, FDI, XM, 
HTE, AR-GE ve PAT) açısından elde edilenler, G-7 ve YPE-9 grubunda yer alan ülkelerin uzun dönemde ekonomik büyüme performanslarının sürdürülebilirliği açısından farklılaşmalarının nereden kaynaklandığını da açıklayabilecek niteliktedir.

\section{Sonuç}

Ülke ekonomilerinin teknolojik gelişme düzeylerine bağlı olan toplam faktör verimliliği artışları, uzun dönemde ekonomik büyümenin temel belirleyicisi olarak kabul edilmektedir. Bu kapsamda, üretimde kullanılan bütün faktörlerin verimliliğini içeren toplam faktör verimliliği artışı üzerinde etkili olan unsurların belirlenmesi ve politikalar yoluyla bu faktörlerde iyileştirmelerin yapılması uzun dönemde potansiyel büyüme hızlarının artırılması ve sürdürülebilir kılınması açısından büyük önem taşımaktadır. Nitekim ilgili literatür incelendiğinde, toplam faktör verimliliğinin ülkeler arasındaki refah düzeyi farklılıklarını açıklamadaki rolü üzerinde durulmakta, toplam faktör verimliliği artışları ile belirleyicilerinin gelişmiş ve gelişmekte olan ülkeler arasındaki gelir farklılıklarının önemli bir bölümünü açıklayabileceği kabul edilmektedir. Bu noktadan hareketle çalışmada, G-7 ile Brezilya, Rusya, Hindistan, Çin, G. Afrika, Meksika, Endonezya, Türkiye ve S. Arabistan gibi hızlı gelişmekte olan yükselen piyasa ekonomilerinde (YPE-9) toplam faktör verimliliğinin belirleyicileri 1992-2013 dönemi için ekonometrik olarak ayrı ayrı incelenmiştir. Bu yönüyle çalışmada G-7 ve YPE-9 ülke gruplarında sürdürülebilir ekonomik büyümenin temelini oluşturan toplam faktör verimliliği artışı üzerinde uzun vadede etkili olan unsurların tespit edilmesi ve ortaya çıan sonuçların ifade ettiklerinin ülke gruplarının ekonomik gelişmişlik seviyesi açısından değerlendirilmesi amaçlanmıştır.

Bu bağlamda, G-7 ve YPE-9 ülke gruplarında fiziksel ve beşeri sermaye düzeyi ile bilgi inovasyon ve teknolojik gelişmişlik seviyesini temsilen kullanılan değişkenlerin toplam faktör verimliliği üzerindeki uzun dönemli etkilerini tespit etmek için tanımlanan farklı modeller paneli oluşturan yatay kesit birimler arasındaki bağımlılı̆̆ı dikkate alan ve almayan yöntemlerle birlikte tahmin edilmiştir. Çalışma sonucunda her iki ülke grubu üzerinde tanımlanan modellerden elde edilen teorik ve ampirik literatürle uyumlu olduğu belirlenen sonuçları şu şekilde ifade etmek mümkün olmaktadır. G-7 ve YPE-9 gruplarında tanımlanan bütün modellerde sabit sermaye yatırımları değişkeninin toplam faktör verimliliği üzerindeki etkisinin pozitif yönlü ve istatistiki olarak anlamlı olduğu ve bu etkinin büyüklüğünün ise beklenildiği gibi YPE9 grubunda daha fazla olduğu sonucuna ulaşılmıştır. Dahası YPE-9 grubunda G-7 grubuna kiyasla sabit sermaye yatırımları değişkeninin TFP üzerindeki pozitif yönlü etkisinin büyüklüğünün bazı modellerde üç kattan daha fazla olduğu tespit edilmiştir. Bununla birlikte, G-7 ve YPE-9 gruplarında tanımlanan istisnasız bütün modellerde istihdam edilen işgücünün, toplam faktör verimliliğini azaltıcı yönde bir etkiye sahip olduğu ve bu etkinin iki ülke grubu arasında ayırt edici derecede önemli farlılıklar oluşturmadığ 1 sonucuna ulaşılmıştır.

Diğer taraftan, G-7 ve YPE-9 grupları arasında uzun dönemde toplam faktör verimliliği artı̧̧ı üzerinde fark yaratan asıl unsurların ülkelerin bilgi, inovasyon ve teknolojik gelişmişlik seviyelerini temsilen kullanılan; aktif nüfusun eğitim seviyesi, doğrudan yabanc1 yatırımlar, ülkelerin dişa açıklık derecesi, araştırma-geliştirme yatırımları, yüksek teknoloji ihracatı ve patent başvuru sayıları şeklindeki değişkenlerde olduğu belirlenmiştir. Nitekim aktif nüfusun eğitim seviyesi, ülkelerin dışa açılılı derecesi, araştırma-geliştirme yatırımları ve patent başvuru sayıları değişkenlerinin yer aldığı modellerde, tüm değişkenlerin TFP üzerindeki etkisinin her iki ülke grubunda pozitif yönlü olduğu ancak bu pozitif yönlü etkinin sadece G-7 grubunda istatistiki açıdan anlamlı olduğu sonucuna ulaşılmıştır. Üstelik G-7 grubunda YPE-9 grubuna kıyasla istatistiki açıdan anlamlı olduğu belirlenen söz konusu değiş̧kenlerden eğitim ve dışa açıklık derecesi değişkenlerinin TFP üzerindeki pozitif yönlü etkisinin büyüklüğünün daha fazla olduğu da belirlenmiştir. Bununla birlikte, doğrudan yabancı yatırımların yer aldığı modellerde, her iki ülke grubunda bu değişkenin toplam faktör verimliliği üzerindeki etkisinin pozitif yönlü ve istatistiki açıdan anlamsız olduğu tespit edilmiştir. Ancak, doğrudan yabancı yatırımlarının TFP üzerindeki pozitif yönlü etkisinin büyüklüğünün beklenildiği gibi G-7 grubunda çok daha fazla olduğu sonucuna ulaşılmıştır. Son olarak, yüksek teknoloji ihracatı değişkeninin yer aldığı modellerde, her iki ülke grubunda yüksek teknoloji ihracatının toplam faktör verimliliği üzerindeki etkisinin pozitif ve anlamlı olduğu ve bu etkinin büyüklügünün G-7 grubunda YPE-9 grubuna kıyasla yaklaşık beş kat daha fazla olduğu belirlenmiştir. 
Özetle, toplam faktör verimliliğinin uzun vadeli belirleyicilerini tespit etmek üzere tanımlanan modellerin bulgular1, G-7 grubunda TFP'nin belirleyicilerinin sırasılya; aktif nüfusun eğitim seviyesi, ülkelerin dışa açıklık derecesi, sabit sermaye yatırımları, araştırma-geliştirme yatırımları, yüksek teknoloji ihracatı ve patent başvuru sayıları şeklinde olduğunu ortaya koymaktadır. Buna karşılık, YPE-9 grubunda toplam faktör verimliliğinin belirleyicileri arasında başta fiziksel sermayeyi temsilen kullanılan sabit sermaye yatırımları olmakla beraber bilgi, inovasyon ve teknolojik gelişmişliği temsilen kullanılan değişkenlerden ise sadece yüksek teknoloji ihracatının yer aldığ sonucuna ulaşılmıştır. Tanımlanan modellerden elde edilen tüm bu sonuçlar, inceleme döneminde G-7 ve YPE-9 grubunda yer alan ülkelerin uzun dönemde ekonomik büyüme performanslarının sürdürülebilirliği açısından farklılaşmalarının büyük ölçüde bilgi, inovasyon ve teknolojik gelişmişlik düzeyini temsilen kullanılan göstergelerden kaynaklandığını ortaya koymaktadır.

Bu kapsamda, hızlı gelişmekte olan yükselen piyasa ekonomilerinde politika yapıcılarının bilgi, inovasyon ve teknolojik gelişmişlik göstergelerinin toplam faktör verimliliği artışı üzerindeki etkilerini güçlendirici yönde makroekonomik politikaları geliştirerek uygulamaları gereklilik arz etmektedir.

Ancak bu yolla gelişmiş ülkelerle aralarındaki gelir farklılıklarını kapatabilmelerinin ve hızla gelişmekte olan yükselen piyasa ekonomileri konumundan gelişmiş ekonomiler seviyesine çıkabilmelerinin mümkün olabileceği çalışmanın sonuçlarından anlaşılmaktadır. Aksi halde, çalışma döneminde G-7 ve YPE-9 gruplarındaki ülkeler arasında bilgi, inovasyon ve teknolojik gelişmişlik düzeyinin TFP üzerindeki etkileri ve gelişmişlik/gelir düzeyi açısından mevcut olan farklılıkların yakın gelecekte de benzer olacağını şimdiden öngörmek mümkün olmaktadır. Tüm bunlara ek olarak, TFP'nin belirleyicilerini incelemek için yakın gelecekte yapılacak ampirik çalışmalarda, gerekli verilerin temin edilebilir olması durumunda daha geniş bir zaman aralığının ve daha fazla sayıda ülkenin kapsanmasının bu konudaki literatürün gelişimine katkı sağlayacağı düşünülmektedir.

\section{Kaynakça}

Abdih, Y., Joutz, F. (2005). Relating the Knowledge Production Function to Total Factor Productivity: An Endogenous Growth Puzzle (IMF Working Paper No. WP/05/74). Washington DC: International Monetary Fund.

Aghion, P., Howitt, P., Mayer-Foulkes, D. (2005). The Effect of Financial Development on Convergence: Theory and Evidence. Quarterly Journal of Economics, 120(1), 173-222.

Aitken, B., Harrison, A. (1999). Do Domestic Firms Benefit from Foreign Direct Investment? Evidence from Venezuela. American Economic Review, 89, 605-18.

Alfaro, L., Ozcan, S. K., Sayek, S. (2009). FDI, Productivity and Financial Development. World Economy, 32(1), 111-135.

Ascari, G., Cosmo, V. D. (2005). Determinants of Total Factor Productivity in the Italian Regions. Scienze Regionali, 4(2), 27-49.

Bartel, A. (1992). Training, Wage Growth and Job Performance: Evidence from a Company Database (NBER Working Paper No. 4027). Cambridge MA: NBER.

Bartelsmann, E. J., Leeuwen V. G., Nieuwenhuijsen, H. R. (1996). Advanced Manufacturing Technology and Firm Performance in the Netherlands. Netherlands Official Statistics, 11, 40-51.

Black, S. E., Lynch, L. M. (1995). Beyond the Incidence of Training: Evidence from a National Employers Survey (NBER Working Paper No. 5231). Cambridge, MA: NBER.

Coe, D. T., Helpman, E. (1995). International R\&D Spillovers. Economic European Review, 39, 859-87.

Coe, D. T., Helpman, E., Hoffmaister, A. W. (1997). North-South R\&D Spillovers. Economic Journal, 107, 134-49. 
Comin, D., (2002). R\&D? A Small Contribution to Productivity Growth (Economic Research Reports No. 2002-01). New York: C.V. Starr Center for Applied Economics, New York University.

Easterly, W., Levine, R. (2002). Tropics, Germs, and Crops: How Endowments Influence Economic Development. Journal of Monetary Economics, 50, 3-39.

Furman, J. L., Hayes, R. (2004). Catching Up or Standing Still? National Innovative Productivity Among "Follower" Countries, 1978-1999. Research Policy, 33, 1329-54.

Göçer, İ., Alataş, S., Peker, O. (2013). Yatırım-Tasarruf İlişkisi: OECD Ülkeleri İçin Yeni Nesil Panel Eşbütünleşme Analizi. Dumlupınar Üniversitesi Sosyal Bilimler Dergisi, EYİ 2013 Özel Sayısı, 59-78.

Göçer, İ., Mercan, M., Hotunluoğlu, H. (2012). Seçilmiş OECD Ülkelerinde Cari İşlemler Açı̆ı̆ının Sürdürülebilirliği: Yatay Kesit Bağımlılığı Altında Çoklu Yapısal Kırılmalı Panel Veri Analizi. Maliye Dergisi, 163, 449-470.

Griffith, R., Redding, S., Simpson, H. (2003). Productivity Convergence and Foreign Ownership at the Establishment Level (Discussion Paper No. 572). London: Centre for Economic Performance.

Griffith, R., Redding, S., Van Reenen, J., (2000). Mapping the Two Faces of R\&D: Productivity Growth in a Panel of OECD Industries (CEPR Discussion Paper No. 2457). London: CEPR.

Guellec, D., Van Pottelsberghe De La Potterie, B. (2001). R\&D and Productivity Growth: Panel Data Analysis of 16 OECD Countries. OECD Economic Studies, 33, 103-26

Gujarati, D. N. (2009). Temel Ekonometri. Ümit Şenesen ve Gülay G. Şenesen (Çev.). İstanbul: Literatür.

Hall, B., Mairesse, J. (1995). Exploring the Relationship Between R-D and Productivity in French Manufacturing Firms. Journal of Econometrics, 65, 263-93.
Hanson, G. (2001). Should Countries Promote Foreign Direct Investment? (G-24 Discussion Paper Series No. 9). Geneva: UNCTAD.

Haskel, J. E., Pereira, S. C., Slaughter, M. J. (2002). Does Inward Foreign Direct Investment Boost the Productivity of Domestic Firms (NBER Working Paper No. 8724). Cambridge, MA: NBER.

Hermes, N., Lensink, R. (2003). FDI, Financial Development and Economic Growth. Journal of Development Studies, 40(1), 142-163.

Isaksson, A. (2001). The Importance of Human Capital for the Trade-Growth Link (UNIDO Working Paper No. 2). Vienna: UNIDO.

Isaksson, A. (2007). Determinants of Total Factor Productivity: A Literature Review (Staff Working Paper No. 02). Vienna: UNIDO.

İzmen, Ü., Filiztekin, A., Yılmaz, K. (2005). Türkiye'de Büyüme Perspektifleri: Makroekonomik Çerçeve: Dinamikler/Strateji (TÜSİAD Büyüme Stratejileri Dizisi No.1). İstanbul: Lebib Yalkın.

Jaumotte F., Spatafora, N. (2007). Asia Rising: A Sectoral Perspective (IMF Working Paper No. 07/130). Washington DC: International Monetary Fund.

Keller, W., Yeaple, S. R. (2003). Multinational Enterprises, International Trade, and Productivity Growth: Firm-Level Evidence from the United States (NBER Working Paper No. 9504). Cambridge, MA: NBER.

Lichtenberg, F. R., Siegel, D. (1991). The Impact of R\&D Investment on Productivity: New Evidence Using Linked R\&D-LRD Data. Economic Inquiry, 29(2), 203-229.

Loko B., Diouf, M. A. (2009). Revisiting the Determinants of Productivity Growth: What's New? (IMF WP No. 09/225). Washington DC: International Monetary Fund.

Mark, N. C., Ogaki, M., Sul, D. (2005). Dynamic Seemingly Unrelated Cointegrating Regressions. Review of Economic Studies, 72, 797-820. 
Mastromarco, C., Zago, A. (2012). On Modelling The Determinants of TFP growth. Structural Change and Economic Dynamics, 23, 373-382.

Miller, S. M., and Upadhyay, M. P. (2000). The Effects of Openness, Trade Orientation, and Human Capital on Total Factor Productivity. Journal of Development Economics, 63, 399-423.

Miller, S. M., Upadhyay, M. P. (2002). Total Factor Productivity, Human Capital, and Outward Orientation: Differences by Stage of Development and Geographic Regions (Economics Working Papers No. 2002-33). http://digitalcommons.uconn.edu/ econ_wpapers/200233.

Nazlığlu, Ş. (2010). Makro İktisat Politikalarının Tarım Sektörü Üzerindeki Etkileri: Gelişmiş ve Gelişmekte Olan Ülkeler İçin Bir Karşılaştırma. (Yayımlanmamış Doktora Tezi). Erciyes Üniversitesi/ Sosyal Bilimler Enstitüsü, Kayseri.

Pesaran, M. H. (2007). A Simple Panel Unit Root Test in The Presence of Cross-Section Dependence. Journal of Applied Econometrics, 22(2), 265-312.

Pesaran, M. H., Ullah, A., Yamagata, T. (2008). A BiasAdjusted LM Test of Error Cross-Section Independence. The Econometrics Journal, 11(1), 105-127.

Saygıll, Ş., Cengiz, C. ve Yurtoğlu, H. (2005), Türkiye Ekonomisinde Sermaye Birikimi, Verimlilik ve Büyüme (1972-2003) Uluslararası Karşılaştırma ve AB’ye Yakınsama Süreci (2014), TÜSİAD Büyüme Stratejileri Dizisi No: 6, Yayın No. TÜSİAD-T/2005-12/413).
Serdaroğlu, T. (2013). Türkiye'de Finansal Açılılk ve Toplam Faktör Verimliliği. Kalkınma Bakanlığ 1 Ekonomik Modeller ve Stratejik Araştırmalar Genel Müdürlüğü Planlama Uzmanlığı Tezi, Yayın No. 2853.

Sevüktekin, M., Çınar, M. (2014). Ekonometrik Zaman Serisi Analizi: EViews Uygulamah (Genişletilmiş 4. Baskı). Bursa: Dora.

Tarı, R. (2010). Ekonometri (6. Baskı). Kocaeli: Umuttepe.

Tatoğlu, F. Y. (2012). Panel veri Ekonometrisi-Stata Uygulamal. İstanbul: Beta.

Tatoğlu, F. Y. (2013). İleri Panel Veri Analizi-Stata Uygulamalı (2. Baskı). İstanbul: Beta.

Ulku, H., (2004). R\&D, Innovation, and Economic Growth: An Empirical Analysis (IMF WP. No. 04/185). Washington, DC: International Monetary Fund.

Westerlund, J., Edgerton, D. L. (2007). A Panel Bootstrap Cointegration Test. Economics Letters, 97(3), 185-190. 